\title{
High-spatial resolution dating of monazite and zircon reveals the timing of subduction-exhumation of the Vaimok Lens in the Seve Nappe Complex (Scandinavian Caledonides)
}

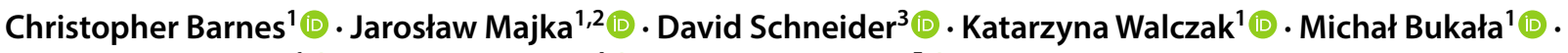 \\ Karolina Kośmińska ${ }^{1}$ (D) . Tomasz Tokarski ${ }^{4}$ (iD $\cdot$ Andreas Karlsson $^{5}$ (D)
}

Received: 12 July 2018 / Accepted: 30 November 2018 / Published online: 21 December 2018

(C) The Author(s) 2018

\begin{abstract}
In-situ monazite $\mathrm{Th}-\mathrm{U}-$ total $\mathrm{Pb}$ dating and zircon LA-ICP-MS depth-profiling was applied to metasedimentary rocks from the Vaimok Lens in the Seve Nappe Complex (SNC), Scandinavian Caledonides. Results of monazite Th-U-total Pb dating, coupled with major and trace element mapping of monazite, revealed $603 \pm 16$ Ma Neoproterozoic cores surrounded by rims that formed at $498 \pm 10 \mathrm{Ma}$. Monazite rim formation was facilitated via dissolution-reprecipitation of Neoproterozoic monazite. The monazite rims record garnet growth as they are depleted in $\mathrm{Y}_{2} \mathrm{O}_{3}$ with respect to the Neoproterozoic cores. Rims are also characterized by relatively high $\mathrm{SrO}$ with respect to the cores. Results of the zircon depth-profiling revealed igneous zircon cores with crystallization ages typical for SNC metasediments. Multiple zircon grains also exhibit rims formed by dissolution-reprecipitation that are defined by enrichment of light rare earth elements, $\mathrm{U}, \mathrm{Th}, \mathrm{P}, \pm \mathrm{Y}$, and \pm Sr. Rims also have subdued Eu anomalies $\left(\mathrm{Eu} / \mathrm{Eu}^{*} \approx 0.6-1.2\right)$ with respect to the cores. The age of zircon rim formation was calculated from three metasedimentary rocks: $480 \pm 22 \mathrm{Ma} ; 475 \pm 26 \mathrm{Ma}$; and $479 \pm 38 \mathrm{Ma}$. These results show that both monazite and zircon experienced dissolution-reprecipitation under high-pressure conditions. Caledonian monazite formed coeval with garnet growth during subduction of the Vaimok Lens, whereas zircon rim formation coincided with monazite breakdown to apatite, allanite and clinozoisite during initial exhumation.
\end{abstract}

Keywords Seve Nappe Complex $\cdot$ Scandinavian Caledonides $\cdot$ Monazite Th-U-total Pb geochronology $\cdot$ Zircon LA-ICP-MS depth-profiling geochronology

Communicated by Daniela Rubatto.

Electronic supplementary material The online version of this article (https://doi.org/10.1007/s00410-018-1539-1) contains supplementary material, which is available to authorized users.

Christopher Barnes

cjbarnes063@gmail.com

1 Faculty of Geology, Geophysics and Environmental Protection, AGH University of Science and Technology, Kraków, Poland

2 Department of Earth Sciences, Uppsala University, Uppsala, Sweden

3 Department of Earth and Environmental Sciences, University of Ottawa, Ottawa, Canada

4 Academic Center for Materials and Nanotechnology, AGH University of Science and Technology, Kraków, Poland

5 Department of Geoscience, Swedish Museum of Natural History, Stockholm, Sweden

\section{Introduction}

To understand the subduction-exhumation dynamics of continental lithosphere that reached (ultra-)high pressure [(U)HP] depths, we must extract information regarding the timing and conditions of prograde, peak and retrograde metamorphism. Problematically, continental lithosphere that experienced (U)HP metamorphism is commonly overprinted by exhumation-related structures and retrogressive metamorphism. Moreover, peak-temperatures of rocks that experienced (U)HP metamorphism are typically reached during decompression. Geochronometers that are sensitive to both thermally activated diffusion and deformation during exhumation can lose the record of the subduction and early exhumation processes as a result.

Robust geochronometers, such as monazite and zircon, are refractory minerals that can retain their geochronological and geochemical signatures through high temperature 
conditions, retrogressive metamorphism and deformation (e.g. Engi 2017; Foster et al. 2000; Harley et al. 2007; Rubatto 2017; Rubatto et al. 2001; Schneider et al. 2011; Skipton et al. 2016; Walczak et al. 2017). However, monazite and zircon domains that record such important information regarding prograde metamorphism are often minute, commonly with volumes on the scale of a few micrometers. As a result, high-spatial resolution techniques must be employed to extract the critical information from the accessory minerals. Monazite electron microprobe Th-U-total $\mathrm{Pb}$ dating can achieve a lateral spot size of $3 \mu \mathrm{m}$ (or less) to simultaneously gather geochronological and trace element data from monazite domains (e.g. Kohn et al. 2005; Krenn et al. 2008; Majka et al. 2012; Petrík and Konečný 2009;
Pyle et al. 2005; Spear et al. 2009; Suzuki and Adachi 1991; Williams et al. 2007, 2017). Zircon depth-profiling, using either Laser Ablation Inductively Coupled Mass Spectrometry (LA-ICP-MS) or Secondary Ion Mass Spectrometry (SIMS), has proven to be a powerful technique to extract radiogenic isotopes and trace elements from micrometerscale rims (e.g. Breeding et al. 2004; Kelly et al. 2014, 2017; Marsh and Stockli 2015; Schneider et al. 2011; Skipton et al. 2016; Woodhead et al. 2004). We applied these techniques to accessory phases hosted in the (U)HP rocks of the Seve Nappe Complex (SNC), Scandinavian Caledonides (Fig. 1), to resolve the early metamorphic evolution of these complex rocks. Monazite and zircon record a fluid-assisted redistribution of trace elements that documents subduction and initial exhumation in high-pressure conditions of the Vaimok Lens.
Fig. 1 Tectonostratigraphic map of the Scandinavian Caledonides (after Klonowska et al. 2017, and references therein). The Seve Nappe Complex (SNC; red) represents continental lithosphere that was subducted to (ultra-)high pressure metamorphic conditions. Previous geochronology for the SNC in northern Jämtland and near Åreskutan are summarized. Our study area in the SNC is the Vaimok Lens, denoted by the black box. Previous geochronological results for the Vaimok Lens are summarized in Fig. 2. References: ${ }^{1}$ Brueckner and van Roermund (2004); ${ }^{2}$ Brueckner and van Roermund (2007); ${ }^{3}$ Fassmer et al. (2017); ${ }^{4}$ Majka et al. (2012)

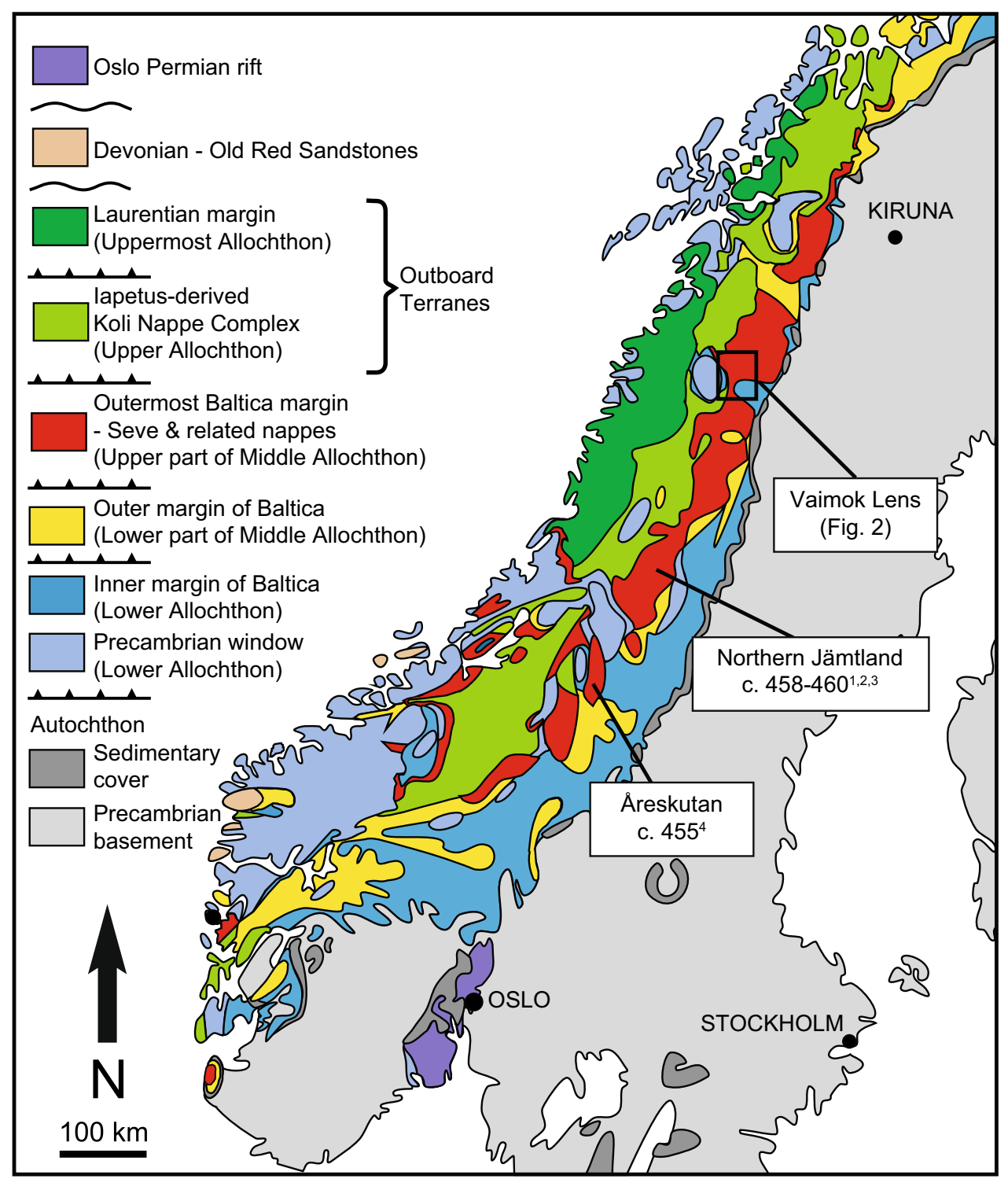




\section{Geological background}

The Seve Nappe Complex (SNC) comprises rocks of the Baltica rifted passive margin that were subsequently subducted to (U)HP conditions (e.g. Albrecht 2000; Brueckner and van Roermund 2004; Bukała et al. 2018; Gilio et al. 2015; Janák et al. 2013; Klonowska et al. 2014, 2016, 2017; Kullerud et al. 1990; Majka et al. 2014; Santallier 1988; Stephens and van Roermund 1984) and constitutes the upper part of the Middle Allochthon of the Scandinavian Caledonides (e.g. Gee et al. 2013). The lower part of the Middle Allochthon is similarly composed of rocks of the outer Baltica passive margin, but did not experience high-pressure metamorphism. The Middle Allochthon overlies rocks of the inner Baltica margin and allochthonous Baltica basement (Lower Allochthon) that are thrusted over autochthonous Baltica basement (Figs. 1, 2). Overlying the SNC is the Köli Nappe Complex of the Upper Allochthon (Figs. 1, 2) consisting of ophiolites, volcanic arc material and deep water sediments derived from the Iapetus Ocean (Stephens 1988). Rocks of the Laurentian margin (Uppermost Allochthon) overthrust the Köli Nappe Complex.

Our study area, the Vaimok Lens (Fig. 2), comprises Neoproterozoic metasediments and felsic metavolcanic rocks hosting metamafic (eclogite) bodies (Albrecht 2000; Andréasson et al. 1985; Bukała et al. 2018; Santallier 1988). The record of prograde to peak metamorphism is nearly obliterated within the metasedimentary rocks, as they are strongly overprinted by exhumation-related deformation and retrogressive metamorphism (Albrecht 2000), the latter also affected a large portion of the eclogitic bodies. As a result, most studies investigating the metamorphic history have relied on extracting information from the few eclogitic bodies that were not strongly overprinted by retrogressive metamorphism. Recent investigation of well-preserved eclogites hosted in the metasediments yielded peak-pressure of $2.8-3.1 \mathrm{GPa}\left(\right.$ at $\sim 700{ }^{\circ} \mathrm{C}$ ) and peak-temperature of $\sim 735^{\circ} \mathrm{C}$ (at $\sim 2.1 \mathrm{GPa}$ ), demonstrating that these rocks reached UHP conditions and experienced nearly isothermal decompression during exhumation (Bukała et al. 2018). Our understanding of the timing of subduction and exhumation, however, remains equivocal. Dallmeyer and Gee (1986) first published a hornblende ${ }^{40} \mathrm{Ar} /{ }^{39} \mathrm{Ar}$ age of $491 \pm 8 \mathrm{Ma}$ from the Vaimok Lens eclogite, interpreted to represent the age of post-eclogite facies cooling. Mørk et al. (1988) reported a garnet-omphacite $\mathrm{Sm}-\mathrm{Nd}$ isochron age of $503 \pm 14 \mathrm{Ma}$, and discussed it as the timing of eclogite-facies metamorphism, corroborating the results of Dallmeyer and Gee (1986). Subsequently, Essex et al. (1997) conducted titanite U-Pb geochronology from the Vaimok Lens metasediments, which yielded dates from c. 500 to c. $475 \mathrm{Ma}$. These were interpreted to represent prograde metamorphism of the Vaimok Lens, contradicting the conclusions of both Dallmeyer and Gee (1986) and Mørk et al. (1988). The most recent study to explore the timing of the metamorphic history for the Vaimok Lens reported a zircon U-Pb ID-TIMS age of $482 \pm 1$ Ma obtained from an unretrogressed eclogite (Root and Corfu 2012), which was taken to reflect the timing of eclogite-facies metamorphism. The latter result supports Essex et al. (1997) and suggests that extraneous ${ }^{40} \mathrm{Ar}$ in hornblende and disequilibrium of $\mathrm{Sm}$ and $\mathrm{Nd}$ systematics in garnet were responsible for the older age estimates.

Farther south in Jämtland, ages of (U)HP metamorphism are considerably younger than in the Vaimok Lens. Previous geochronological studies have resolved the timing of peak-pressure metamorphism in northern Jämtland at c. 460-458 Ma (Brueckner and van Roermund 2007; Brueckner et al. 2004; Fassmer et al. 2017), and c. 455 Ma (Majka et al. 2012) for the Åreskutan locality in central Jämtland (Fig. 1). Resolving the differences between the Vaimok Lens and the Jämtland localities is crucial for understanding the dynamics of diachronous subduction of the SNC in the Vaimok Lens compared to the Jämtland localities.

\section{Sample descriptions}

Four samples from the Vaimok Lens were utilized for this study (Fig. 2): two samples from the south of the area (UTM Zone 33), NB22 (metapelite; 563,607.47E, 7,377,801.66N) and NB23 (metapsammite; 563,779.35E, 7,378,240.48N), and two samples from the north, NB13 (quartzite with metapelitic laminae; 561,881.38E, 7,396,709.53N) and NB14 (metapelite; 561,553.18E, 7,396,973.67N). All the samples exhibit dominantly amphibolite-facies assemblages. Major minerals that define the rock structure in all samples include quartz, plagioclase, white mica, minor amounts of biotite or chlorite replacing white mica, and clinozoisite. Garnet is also found within the majority of the metasediments. The samples can also contain tourmaline, apatite, allanite, monazite, and zircon as accessory minerals, but are not present in all rocks. Euhedral to subhedral zircon grains were observed in thin section for samples NB13, NB14 and NB23.

The clinozoisite in all samples is found as large, elongate porphyroblasts aligned to the retrogressive mineral foliation, predominantly defined by the alignment of white mica and quartz ribbons. In samples NB22 and NB23, clinozoisite forms coronas around allanite and apatite cores. In some instances, these cores also contain monazite, thus preserving the breakdown of monazite to apatite, allanite and clinozoisite (see e.g. Finger et al. 1998; Broska et al. 2005; Lo Pò et al. 2016). Similar clinozoisite coronas are found in NB13, 
Fig. 2 Tectonostratigraphic map of the Vaimok Lens (after Bukała et al. 2018). Sample locations for this study are indicated according to the accessory mineral analyzed from the sample. All samples are metasedimentary rocks obtained from the eclogite-bearing Grapesvare Nappe. Results and locations of previous geochronological studies are summarized. References: ${ }^{1}$ Dallmeyer and Gee (1986); ${ }^{2}$ Essex et al. (1997); ${ }^{3} \mathrm{Mørk}$ et al. (1988); ${ }^{4}$ Root and Corfu (2012)

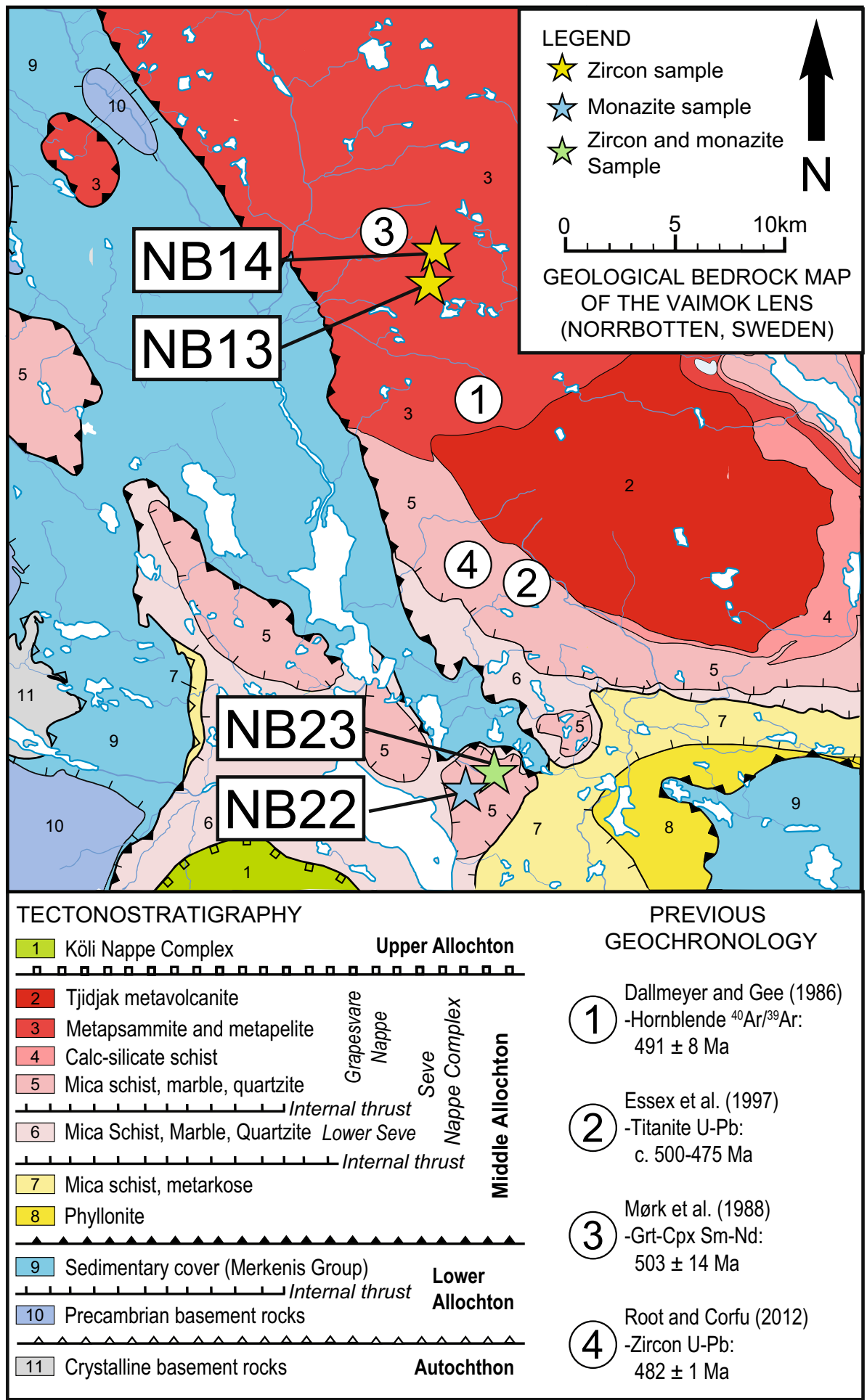

however, any traces of monazite, apatite or allanite within the clinozoisite coronas are not observed, instead, the cores include minerals such as bastnäsite and sulphur-bearing phases. In NB14, small fragments of apatite and clinozoisite are entrained in the high-strain mica-fish structures and could represent the same reaction as in the other samples, but their original relationships are no longer preserved.
Garnet is abundant within both NB22 and NB14, exhibiting only minor resorption and reaction to biotite and chlorite, respectively, at the margins of the garnet. However, geochemistry of the garnet and the mineral inclusions are significantly different for NB22 and NB14. The NB22 garnet is unzoned with respect to major cations and contains inclusions such as monazite and rutile, 
whereas NB14 preserves prograde growth-zoning (e.g. bell-shaped Mn-zoning; Supplementary Fig. A1) and contains inclusions of apatite and ilmenite. Unzoned garnet is not found in NB14. When considering metasedimentary samples of the Vaimok Lens obtained in the area between NB13/NB14 and NB22/NB23 locations (Supplementary Fig. A1), it is revealed that homogenized garnet is overgrown by garnet that preserves growth-zoning. In samples NB13 and NB23, small, partially resorbed garnet remnants are found within chlorite clusters. The significant resorption of the garnet renders identification of inclusions and zoning patterns to be nearly impossible. However, unlike other samples, NB23 also preserves staurolite that suggests that garnet grew along the prograde metamorphic pathway.

\section{Methods}

\section{In-situ monazite geochronology}

Standard $30 \mu \mathrm{m}$ polished thin sections cut for petrographical analysis were utilized for in-situ monazite Th-U-total $\mathrm{Pb}$ dating. Detection and chemical mapping of monazite was conducted using the JEOL JXA8230 electron microprobe (EMP) at AGH University of Science and Technology (Kraków, Poland) with operating conditions of 100 $\mathrm{nA}, 15 \mathrm{kV}$ and a dwell time of $100 \mathrm{~ms}$. Monazite grains were imaged using BSE, and wavelength-dispersive spectrometry (WDS) mapping was conducted for elements $\mathrm{Al}$, $\mathrm{Ca}, \mathrm{Th}, \mathrm{U}$, and $\mathrm{Y}$, whereas energy-dispersive spectrometry (EDS) was used to measure elements $\mathrm{Ce}, \mathrm{Fe}, \mathrm{La}, \mathrm{Nd}, \mathrm{P}$, and S. In-situ dating of monazite was conducted using the Th-U-total $\mathrm{Pb}$ method at the State Geological Institute (Bratislava, Slovakia), using a Cameca SX 100 electron microprobe and following the methodology detailed in Konečný et al. (2018). A $3 \mu \mathrm{m}$ spot was utilized with operating conditions of $15 \mathrm{kV}$ and $180 \mathrm{nA}$. Each analysis was conducted for $20 \mathrm{~min}$.

Analytical spots on the monazite were chosen according to both EMP chemical maps and BSE images. The chemical maps of Th and U clearly displayed the zoning of monazite, and thus were primarily used for determining the location of analytical spots (Fig. 3; Supplementary Fig. A2). The other chemical maps (i.e. P, Ca, S, Ce) were considered to ensure the targeted monazite domain was not disturbed by retrogressive breakdown to apatite and allanite. Many of the monazite fractures, voids and surface irregularities are masked in the chemical maps whereas BSE images which displayed such features. Therefore, the BSE images were consulted to avoid analyzing domains with such features.

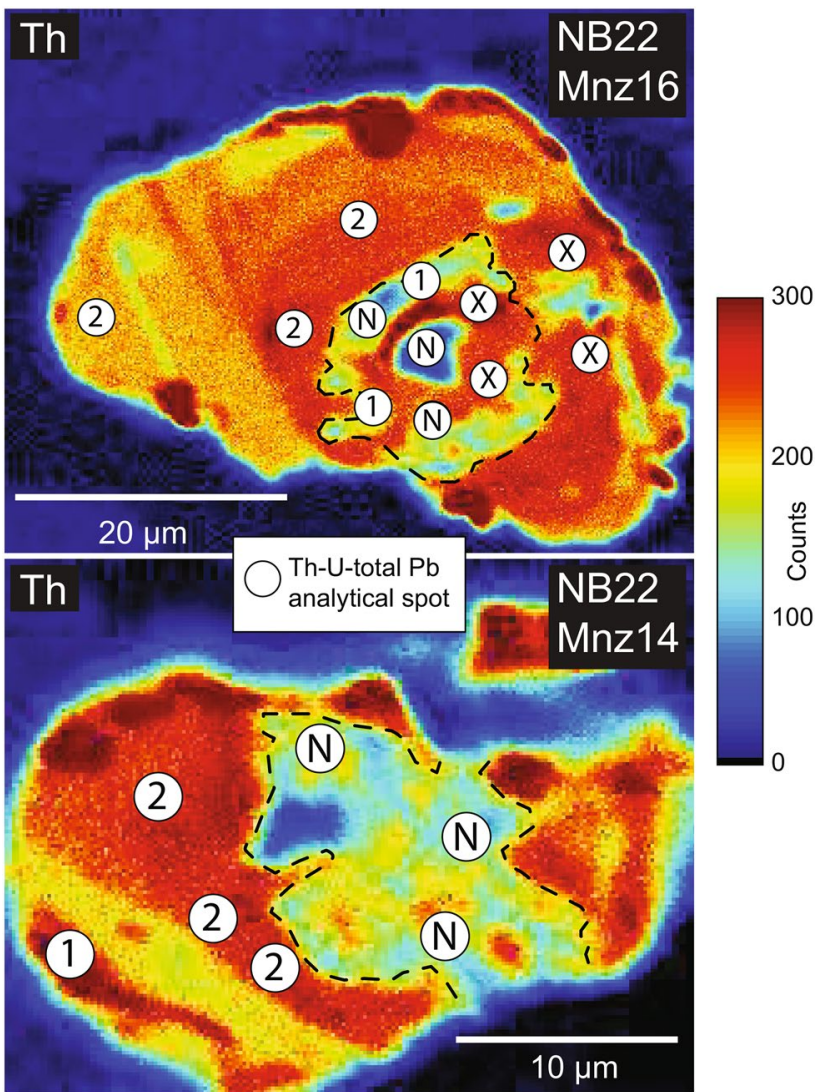

Fig. 3 Electron microprobe (EMP) chemical map (Th) of two monazite grains. Analytical spot locations for $\mathrm{Th}-\mathrm{U}-$ total $\mathrm{Pb}$ analysis are indicated by the white circles. The letter, or number, in each white circle denotes how that point was discriminated with regards to $\mathrm{Th}-\mathrm{U}-$ total $\mathrm{Pb}$ date and monazite chemistry (i.e. $\mathrm{N}-$ Neoproterozoic, 1-Group 1 Cambrian/Ordovician, 2-Group 2 Cambrian/Ordovician, X-Discarded analysis). Black dashed lined demarcates the approximate boundary between the Neoproterozoic core and Caledonian rim

\section{Zircon LA-ICP-MS depth-profiling}

All metasedimentary samples obtained from the Vaimok Lens were crushed using a standard jaw crusher. The crushed rock was separated into three grain size fractions: $>250 \mu \mathrm{m}, 250-63 \mu \mathrm{m}$ and $<63 \mu \mathrm{m}$. The middle size fraction was rinsed with water then acetone, dried and a hand magnet was used to eliminate magnetic material. High-density minerals within this size fraction were separated from lighter minerals using methylene iodide $\left(\mathrm{S} . \mathrm{G} .3 .3 \mathrm{~g} / \mathrm{cm}^{3}\right.$ ) in a separatory funnel. The heavy mineral fraction was then further isolated using a Frantz isodynamic separator. Zircon grains were hand-picked from the non-magnetic fraction using a binocular microscope, and were successfully extracted from samples NB13, NB14 and NB23. Zircon grains were mounted in indium within an aluminum disc, with crystal faces parallel to the mount surface and the grains were not polished. The 
zircon mount was imaged at AGH University of Science and Technology (Kraków, Poland) with a FEI Quanta 200 scanning electron microprobe (SEM) operating under low-vacuum conditions with a $20 \mathrm{kV}$ accelerating voltage. Both back-scattered electron (BSE) and secondary electron (SE) images were acquired to detect fractures, surface overgrowths and surface abrasion or irregularities.

Depth-profiling of the zircon grains was conducted at the University of New Brunswick's LA-ICP-MS Laboratory (Fredericton, Canada), using a Resonetics S-155-LR $193 \mathrm{~nm}$ Excimer laser ablation system coupled to an Agilent 7700x quadrupole ICP-MS. Zircon FC-1 (U-Pb: $1099 \pm 1 \mathrm{Ma}$; Paces and Miller 1993) and Plešovice zircon (U-Pb: $337.13 \pm 0.37 \mathrm{Ma}$; Sláma et al. 2008) were used for geochronological reference material. NIST 610 was used as the trace element reference material. Both the geochronological and trace element references were analyzed at the beginning and end of each sample, as well as intermittently between every 3 and 6 unknowns.

We utilize the laboratory protocols for $\mathrm{U}-\mathrm{Pb}$ dating of zircon via LA-ICP-MS outlined by McFarlane and Luo (2012). Our method for acquiring both trace element and geochronological isotopic data involved ablating two pits on every zircon grain, each with a $33 \mu \mathrm{m}$ lateral spot size (Supplementary Fig. A3). The ablation pits were placed adjacent to each other on the same crystal face. Careful placement of the ablation pit locations ensured that the second ablation did not intersect the previously ablation. The first ablation pit (hereafter referred to as 'Ablation Pit 1') used a $3 \mathrm{~Hz}$ repetition rate and was pulsed for a total of $206 \mathrm{~s}$ with a total quadrupole sweep time of $0.543 \mathrm{~s}$, analyzing elements $\mathrm{P}, \mathrm{Ti}, \mathrm{V}, \mathrm{Sr}, \mathrm{Y}$, Rare Earth Elements (REE), Hf, as well as $\mathrm{U}$, Th and $\mathrm{Pb}$ isotopes. The second ablation pit (hereafter referred to as 'Ablation Pit 2') utilized a $2.5 \mathrm{~Hz}$ repetition rate and was pulsed for a total of $\sim 15 \mathrm{~s}$ with a total quadrupole sweep time of $0.316 \mathrm{~s}$, and only analyzed $\mathrm{U}, \mathrm{Th}$ and $\mathrm{Pb}$ isotopes. The raw data from both ablation pits was reduced with Iolite v.2.5 software (Paton et al. 2011) using VisualAge data reduction scheme for geochronology (Petrus and Kamber 2012) and Trace_Element_IS for all trace elements. The first $\sim 1 \mathrm{~s}$ of data for both Ablation Pits was discarded from analysis. Since the total pulsing time for Ablation Pit 1 was 206 s, separate Iolite files were produced for each $30 \mathrm{~s}$ interval of the ablation (i.e. 0-30 s, 30-60 s, 60-90 s, etc.). This enabled us to detect small variations in trace elements and $\mathrm{U}-\mathrm{Pb}$ dates over a long total ablation time. As well, subdividing the long ablation time resulted in more accurate downhole fractionation corrections for each $30 \mathrm{~s}$ interval, as opposed to a single downhole fractionation correction for the entire ablation time. Both standards and unknowns were processed in the same way.

\section{Internal imaging of zircon grains}

To expose the interior of the zircon, select grains were extracted from the indium mount and re-mounted in a new mount with up to 3 aligned zircon grains. The grains were cut using a Hitachi IM4000Plus argon ion milling system. Specimens to be cut were positioned in a hollow aluminum holder filled with the soft indium metal. A mask was aligned with the zircon grains such that the edge of the mask was aligned along the ablation pits of the zircon. The parts of the zircon grains not covered by the mask were removed by the ion beam operated at $6 \mathrm{kV}$. As a result, zircon grains were cut in half, parallel to the depth-profiles. Cut zircon grains were gold-coated and then imaged at the Swedish Museum of Natural History using an FEI Quanta 650FEG-SEM operated at $15 \mathrm{kV}$ to investigate chemical domains of the zircon interiors.

\section{Zirconium-in-rutile thermometry}

Standard $30 \mu \mathrm{m}$ polished thin sections were utilized for Zr-in-Rutile thermometry (Zack et al. 2004; Tomkins et al. 2007). Rutile inclusions within garnet were targeted for this method. Analyses were conducted at AGH University of Science and Technology (Kraków, Poland), using a JEOL JXA8230 electron microprobe. The analytical procedure followed the protocol of Bukała et al. (2018) and utilized a $1 \mu \mathrm{m}$ spot was utilized for WDS with operating conditions of $15 \mathrm{kV}$ and $120 \mathrm{nA}$.

\section{Results}

\section{In-situ monazite geochronology}

In total, we conducted 93 analyses on monazite from two samples according to different domains primarily defined by $\mathrm{Th}$ and $\mathrm{U}$ concentrations. Twenty-eight of the analyses were discarded due to anomalous chemistry (i.e. low $\mathrm{P}_{2} \mathrm{O}_{5}$, high $\mathrm{FeO}$, oxide wt $\%$ totals $>102$ ). Of the accepted 65 analyses, 49 were from NB22 and 16 from NB23. Primary discrimination according to the $\mathrm{Th}-\mathrm{U}-$ total $\mathrm{Pb}$ dates for the samples shows that eight analyses for NB22 and three analyses for NB23 yielded Neoproterozoic dates (c. 573-667 Ma) whereas 41 analyses for NB22 and 13 analyses for NB23 yielded Cambrian-Ordovician dates (c. 479-536 Ma; Fig. 4; Supplementary Table A1). Neoproterozoic dates were obtained in the central part of monazite grains defining 'cores' relatively lower in Th and U, whereas the relatively higher $\mathrm{Th}$ and $\mathrm{U}$ domains that surrounded the cores yielded Cambrian/Ordovician domains. 


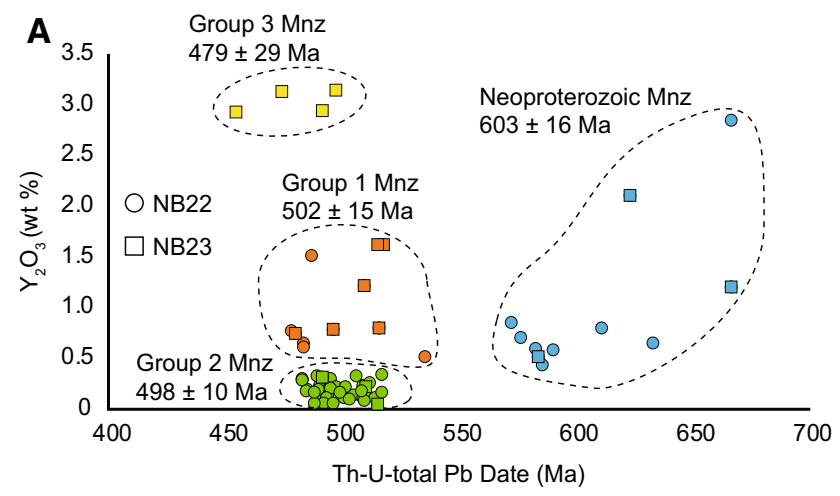

Fig. 4 Chemical discrimination plots subdividing Cambrian/Ordovician analyses, and comparing/contrasting chemistry of Cambrian/ Ordovician with Neoproterozoic analyses. a Date (Ma) vs. $\mathrm{Y}_{2} \mathrm{O}_{3}$ (wt $\%$ ) discrimination plot to distinguish Neoproterozoic, Group 1, Group

The boundary between the two groups is irregular and lobate (Fig. 3).

To discriminate different chemical groups of Cambrian-Ordovician monazite, and to evaluate the Cambrian-Ordovician domains with respect to the Neoproterozoic ones, we used Date vs. $\mathrm{Y}_{2} \mathrm{O}_{3}$ and $\mathrm{SrO}$ vs. $\mathrm{ThO}_{2}$ discrimination plots (Fig. 4). For both samples, the Neoproterozoic analyses are between 0.43 and $1.20 \mathrm{Y}_{2} \mathrm{O}_{3} \mathrm{wt} \%$ (mean 0.70) with the exception of two outliers (2.10 and $\left.2.80 \mathrm{Y}_{2} \mathrm{O}_{3} \mathrm{wt} \%\right)$. The Cambrian-Ordovician analyses can be further subdivided based on $\mathrm{Y}_{2} \mathrm{O}_{3}$ wt $\%$. For both samples, Group 1 is similar to the Neoproterozoic domains with $0.51-1.62 \mathrm{Y}_{2} \mathrm{O}_{3} \mathrm{wt} \%$ (mean 0.98), whereas Group 2 is defined by $<0.35 \mathrm{Y}_{2} \mathrm{O}_{3}$ wt $\%$ (mean 0.18 ). The subordinate Group 3 contains between 2.93 and $3.14 \mathrm{Y}_{2} \mathrm{O}_{3}$ wt\% (mean 3.03).

Neoproterozoic analyses are between 0.95 and $5.08 \mathrm{ThO}_{2}$ $\mathrm{wt} \%$ (mean 2.78) and 0.05-0.32 $\mathrm{UO}_{2} \mathrm{wt} \%$ (mean 0.16), Group 1 between 0.86 and $4.38 \mathrm{ThO}_{2} \mathrm{wt} \%$ (mean 2.62) and $0.25-0.37 \mathrm{UO}_{2}$ wt $\%$ (mean 0.26 ), and Group 2 yields elevated values of 4.24-7.71 $\mathrm{ThO}_{2} \mathrm{wt} \%$ (mean 5.27) with one outlier at 1.77, and 0.28-0.59 $\mathrm{UO}_{2} \mathrm{wt} \%$ (mean 0.46). Examination of the analytical spot spatial distribution reveals that Group 1 domains reside near the margins of the Neoproterozoic domains, whereas Group 2 are distal (Fig. 3).

The Neoproterozoic analyses yielded $0.01-0.42 \mathrm{SrO}$ wt $\%$ (mean 0.18; Fig. 4). Group 1 is similar to the Neoproterozoic with values of $0.02-0.44 \mathrm{SrO}$ wt\% (mean 0.16). Group 2 values are $0.05-0.79 \mathrm{SrO}$ wt\% (mean 0.35 ) showing overall higher values than the Neoproterozoic and Group 1 domains (Fig. 4). Group 3 cluster between 0.02 and $0.03 \mathrm{wt} \%$ (mean $0.03)$.

Due to the similar geochemical traits of the monazite domains from NB22 and NB23 (Fig. 4), and the fact that the samples NB22 and NB23 were collected a few $100 \mathrm{~m}$ apart (Fig. 2), we grouped the results from both samples

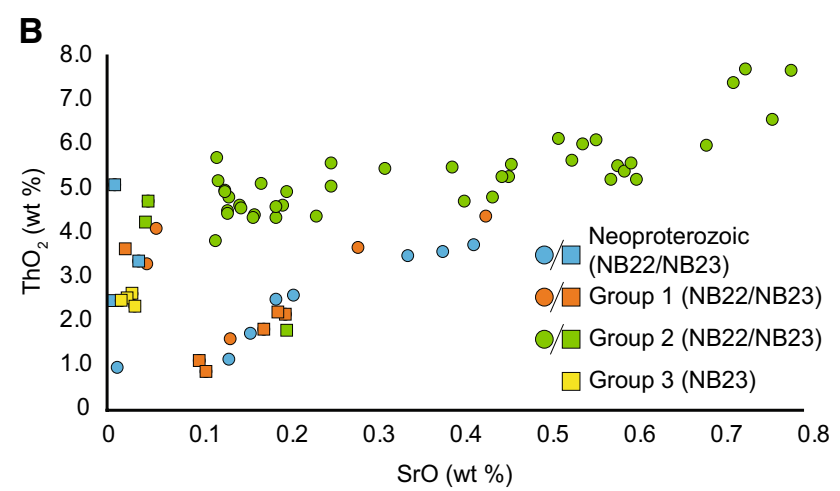

2, and Group 3 monazite. b $\mathrm{SrO}$ (wt \%) vs. $\mathrm{ThO}_{2}$ (wt \%) discrimination plot demonstrating the higher content of both $\mathrm{SrO}$ and $\mathrm{ThO}_{2}$ in Group 2 monazite relative to the other classifications. The pattern of $\mathrm{UO}_{2}$ content mimics $\mathrm{ThO}_{2}$

to calculate our monazite ages. The weighted average of the older population is $603 \pm 16 \mathrm{Ma}$ (n: 11, MSWD: 1.10). The weighted averages for the Cambrian-Ordovician Group 1, Group 2 and Group 3 dates are $502 \pm 15 \mathrm{Ma}$ (n: 11 MSWD: 0.74) and 498 $\pm 10 \mathrm{Ma}$ (n: 39, MSWD: 0.48), and $479 \pm 29 \mathrm{Ma}$ (n: 4, MSWD: 0.43), respectively. Errors are reported according to the internal errors calculated with the weighted mean (if $>2 \%$ of weighted mean) or with a minimum error of $2 \%$ of the weighted mean (if calculated internal error is $<2 \%$ ), according to Spear et al. (2009).

\section{Zircon LA-ICP-MS depth-profiling}

A total of 231 zircon grains (NB13, n: 62; NB14, n: 87; NB23, n: 82) were picked on the basis of size and shape, that were devoid of fractures, and were not heavily abraded or contained visible inclusions. Back-scattered electron images revealed that the majority of zircon grains from the three samples exhibited euhedral crystal faces with sharp edges. Some zircon grains were slightly rounded, but crystal faces could still be observed. The surfaces of NB13 zircon are observed to be very smooth with little surface irregularities and very minor outgrowths The surfaces of NB23 and NB14 varied from smooth to very mottled and irregular (Supplementary Fig. A4). Overall, fracturing was not a prominent feature for the grains of all samples; only few grains displayed moderate-heavy fracturing. Zircon grains for all samples were typically $100-200 \mu \mathrm{m}$ in length with $2: 1$ or $3: 1$ aspect ratios. Back-scattered electron images of zircon cross sections, cut parallel to the depth-profile pits, show thin, discontinuous, concave-inwards, BSE-bright (corresponding to CL-dark) zones at the surface of the crystal (Fig. 5). The margins of BSE-bright zones appear to be associated with $\mu \mathrm{m}$-scale pores in the zircon grain. Minor inclusions have been identified within the BSE-bright zones. 

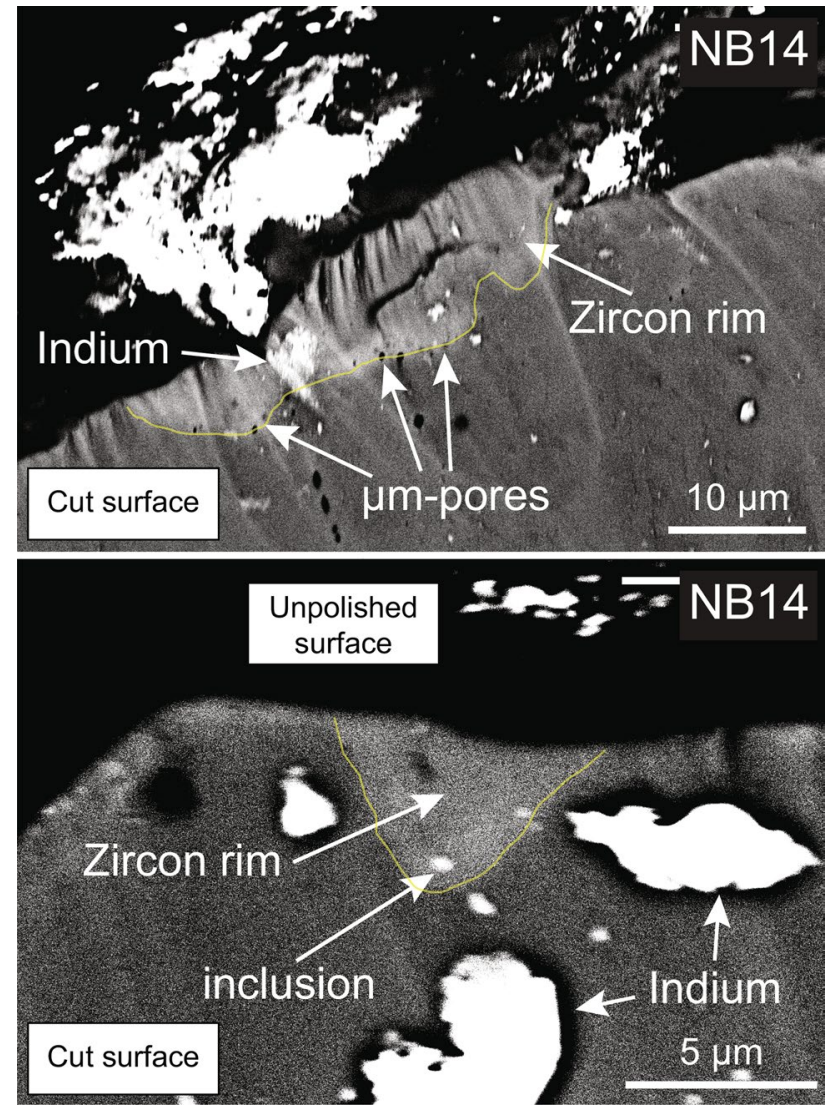

Fig. 5 Back-scattered electron images of cut zircon surfaces. Top: the cut surface displays concave-inwards BSE-bright zone with umscale pore spaces located along the BSE-bright boundary. The irregular, 'wavy' texture of the zircon near the grain edge is a product of the Argon-ion mill. Bottom: the cut surface displays a sharp BSEbright embayment with a single, bright inclusion. Secondary electron images were used to distinguish inclusions from indium matter that was also on the cut surfaces

Results of Ablation Pit 1 were plotted as concentration profiles with respect to ablation time (Fig. 6) to reveal inclusions, define possible rims, and geochemically characterize the cores. Zircon cores from the results of Ablation Pit 1 were defined by flat trace element profiles that extend across the majority of the depth-profile. Inclusions and fractures could be identified based on chemical anomalies and oscillations in the trace element plateaus (Fig. 6). Ideally, four $30 \mathrm{~s}$ integrations were made for the zircon core (spanning $\sim 0$ to $120 \mathrm{~s}$ ), but the amount of inclusions or fractures intersected by the depth-profile sometimes dictated less integrations or integrations defined for $<30 \mathrm{~s}$. The integrations were limited to the $\leq 120 \mathrm{~s}$ of the profile to ensure that integrations strictly defined the zircon core and did not include the opposing zircon rim, if present. A weighted average of the ${ }^{207} \mathrm{~Pb} /{ }^{206} \mathrm{~Pb}$ ages was calculated from the collective integrations for a single zircon core (Fig. 6). Dates for the cores were not corrected for ${ }^{204} \mathrm{~Pb}$ as this frequently produced
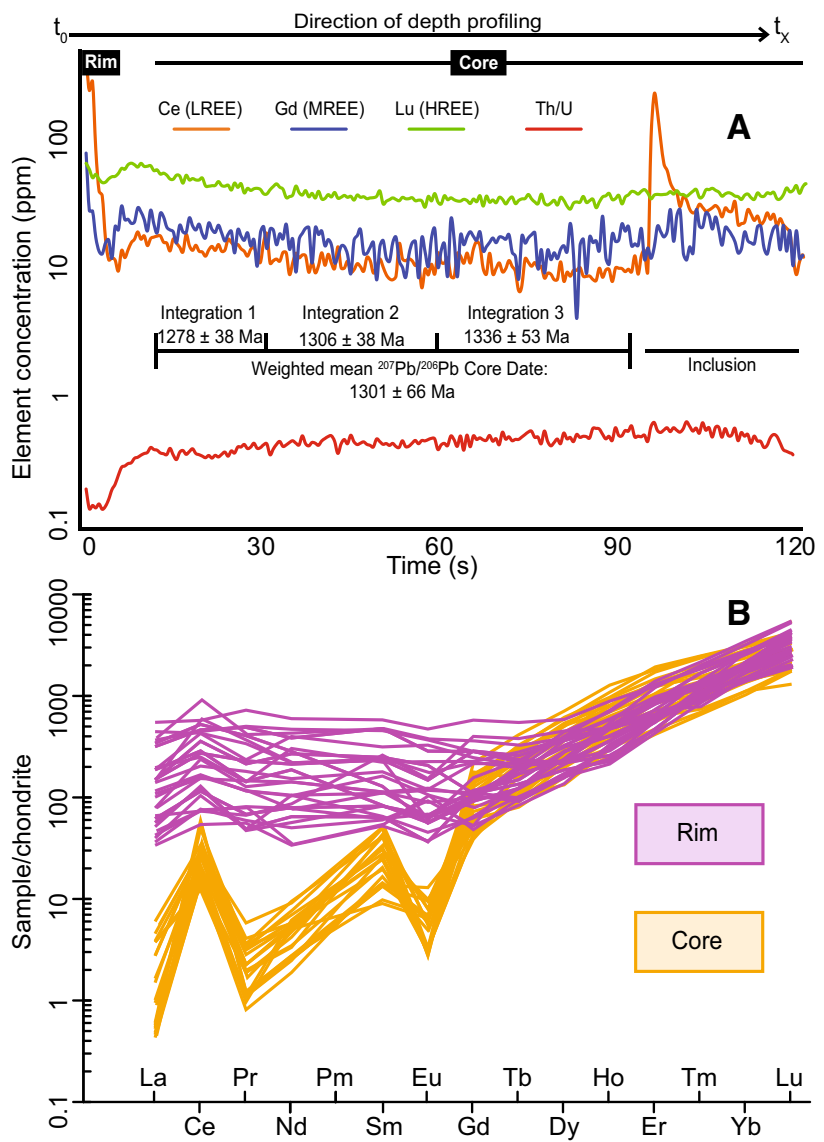

Fig. 6 a Representative plot of Rare Earth Elements concentration (ppm) vs. time (s) for a depth-profile on a single grain (NB13-21). The results presented are from Ablation Pit 1 . The ${ }^{207} \mathrm{~Pb} /{ }^{206} \mathrm{~Pb}$ dates for the zircon cores were integrated in $\leq 30 \mathrm{~s}$ intervals to subdue the uncertainty introduced by the down-hole fractionation correction. $\mathbf{b}$ Compilation of chondrite-normalized Rare Earth Element (REE) content demonstrating the differences between zircon and core chemistry. Note that errors for LREE can be up to $30 \%$ of reported concentration. Representative results of 23 zircon grains were used for the compilation (NB13: 9, NB14: 7, NB23: 7)

reversely-discordant dates. The results from NB13 (Fig. 7) revealed the majority of the zircon cores yielded ${ }^{207} \mathrm{~Pb} /{ }^{206} \mathrm{~Pb}$ dates of c. 990-1240 Ma (n: 47), a subordinate population between c. 1301 and $1486 \mathrm{Ma}$ (n: 11), and scattered dates from c. 1656 to $2635 \mathrm{Ma}$ (n: 4). For NB14, a similar signature is revealed with a cluster at c. $887-1229 \mathrm{Ma}$ (n: 51), and a secondary population in the range of c. 1340-1764 Ma (n: 35). Lastly, NB23 yielded a relative continuum between $\mathrm{c}$. 874 and c. $1883 \mathrm{Ma}$ (n: 70), with isolated dates between c. 2135 and c. $3481 \mathrm{Ma}$ (n: 5).

Numerous zircon grains possess geochemically distinct rims with a total of 109 out of 231 zircon grains (NB13, n: 29; NB14, n: 47; NB23, n: 33) exhibiting LREE enrichment within the first 1-7 s of the ablation (Fig. 6; Supplementary Table A2a,b,c). The LREE are observed to be enriched up to $\sim 600 \mathrm{ppm}$ in the rims and have smaller Eu anomalies 


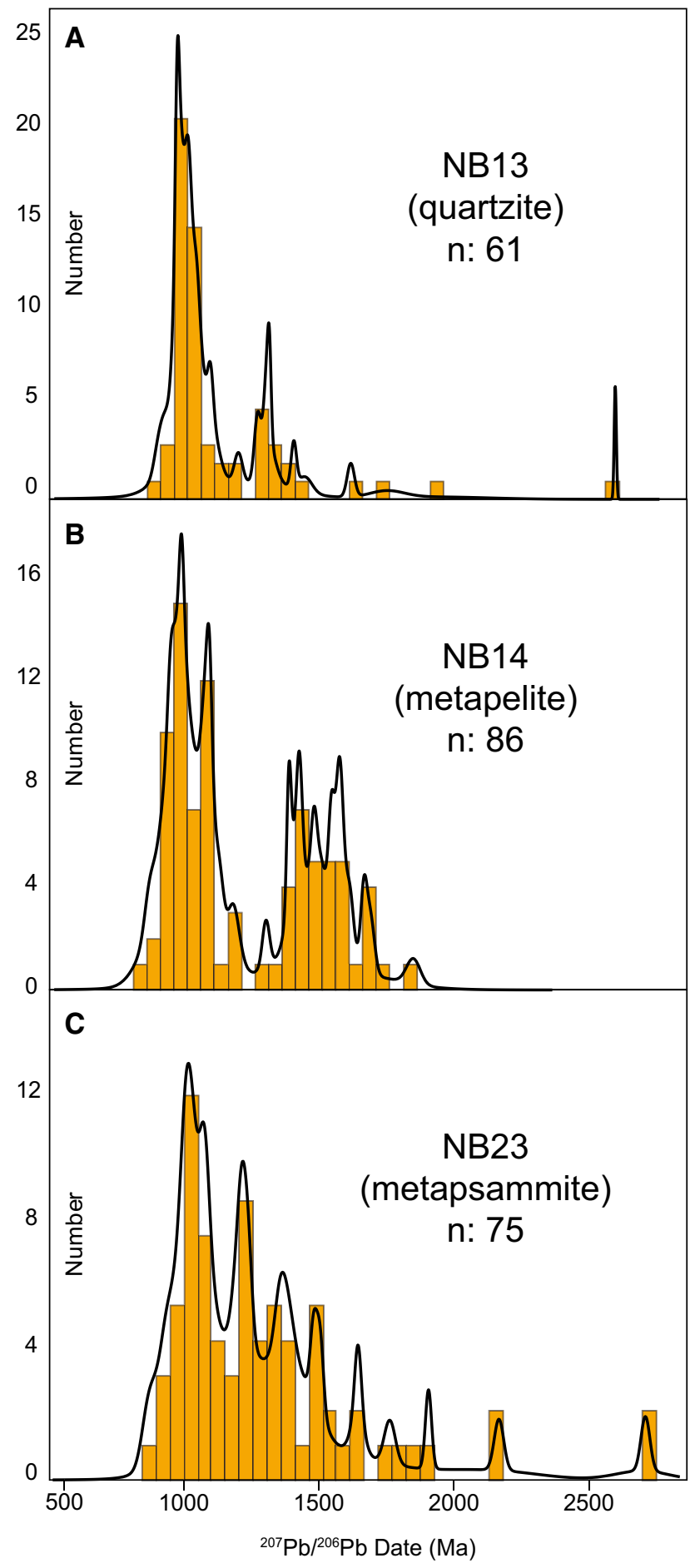

Fig. 7 Histograms and relative probability curves for the results of xenocrystic zircon core ${ }^{207} \mathrm{~Pb} /{ }^{206} \mathrm{~Pb}$ dates for each sample. Note the difference in scale for the $Y$-axes

$\left(\mathrm{Eu} / \mathrm{Eu}^{*} \approx 0.6-1.2 ; \mathrm{Eu} / \mathrm{Eu}^{*}=\mathrm{Eu}_{\mathrm{N}} /\left[\sqrt{ } \mathrm{Sm}_{\mathrm{N}} \times \mathrm{Gd}_{\mathrm{N}}\right]\right)$ than the cores (Fig. 6). In the LREE enriched rims, HREE were slightly elevated by up to $100 \mathrm{ppm}(\mathrm{Lu}$; NB13, n: 20; NB14, n: 23; NB23, n: 21), equal to (NB13, n: 9; NB14, n: 22;
NB23, n: 8), or slightly depleted by up to $\sim 100 \mathrm{ppm}(\mathrm{Lu}$; NB13, n: 0; NB14, n: 2; NB23, n: 4) relative to core values. Enrichment of Th and U (corresponding to lower $\mathrm{Th} / \mathrm{U}$ ratios), $\mathrm{P}, \mathrm{Y}$, and $\mathrm{Sr}$ are observed for LREE enriched rims, except for NB13 which does not show a coincident increase in P. Enrichment of Ti in the grain margins is also observed, but does not necessarily correspond to LREE enrichment. A minor amount of grains showed LREE depletion (NB13, n: 12; NB14, n: 9; NB23 n: 11) relative to core values. The remaining grains showed no change in LREE or HREE in the margins of the grains, or other distinct patterns were not distinguishable based on the trace element profiles.

Zircon rim dates were defined from analyses of Ablation Pit 2, according to ${ }^{206} \mathrm{~Pb} /{ }^{238} \mathrm{U}$ and $\mathrm{Th} / \mathrm{U}$ ratios (Supplementary Table A3), the decrease of the latter correlates to the enrichment of LREE observed in the trace element concentration profiles from Ablation Pit 1. In accordance with previous depth-profiling studies (March and Stocki 2015; Kelly et al. 2017; Skipton et al. 2016), we utilized the Wetherill Concordia diagram to plot our rim integrations. However, in contrast to these studies (i.e. Kelly et al. 2017; Skipton et al. 2016) we did not apply a ${ }^{204} \mathrm{~Pb} /{ }^{206} \mathrm{~Pb}$ cut-off for screening the data as the uncertainties of the ratio often equalled the reported value, thus this cut-off method was deemed unreliable for our data. Instead, we applied the ${ }^{204} \mathrm{~Pb}$-correction built into VisualAge data reduction scheme (Petrus and Kamber 2012) to all rim integrations. Corrected rim integrations that had reverse discordance were discarded and the uncorrected integration was instead accepted at the $>70 \%$ concordance level. This approach defined a broad cluster of zircon dates with variable discordance in Wetherill Concordia space, ranging from 70 to $99 \%$.

Zircon from metasedimentary rocks are likely detrital and possess a spectrum of ages that represent the provenance of the sediment, which is corroborated by the core ages reported here. In a simple binary mixing model, calculating a single regression line from an individual core-rim analysis pair would produce a single lower-intercept and a single upper-intercept, defining the rim formation and the initial crystallization of the zircon, respectively. However, this approach is not able to capture the entire distribution of detrital core ages with a single upper-intercept, in turn biasing the calculated lower-intercept. To fully represent the entire range of zircon core ages and prevent such biasing, we developed a new method for discordance regression. The method involves calculation of a single discordance regression line for every core-rim pair in Wetherill Concordia space (Fig. 8) using the core integrations from Ablation Pit 1 and the rim integrations from Ablation Pit 2. We assume that the isotopic ratios for the zircon cores obtained from Ablation Pit 1 represent the starting isotopic ratios for the zircon rims, analyzed in Ablation Pit 2, prior to rim formation. We then fixed the upper intercept in Wetherill Concordia 

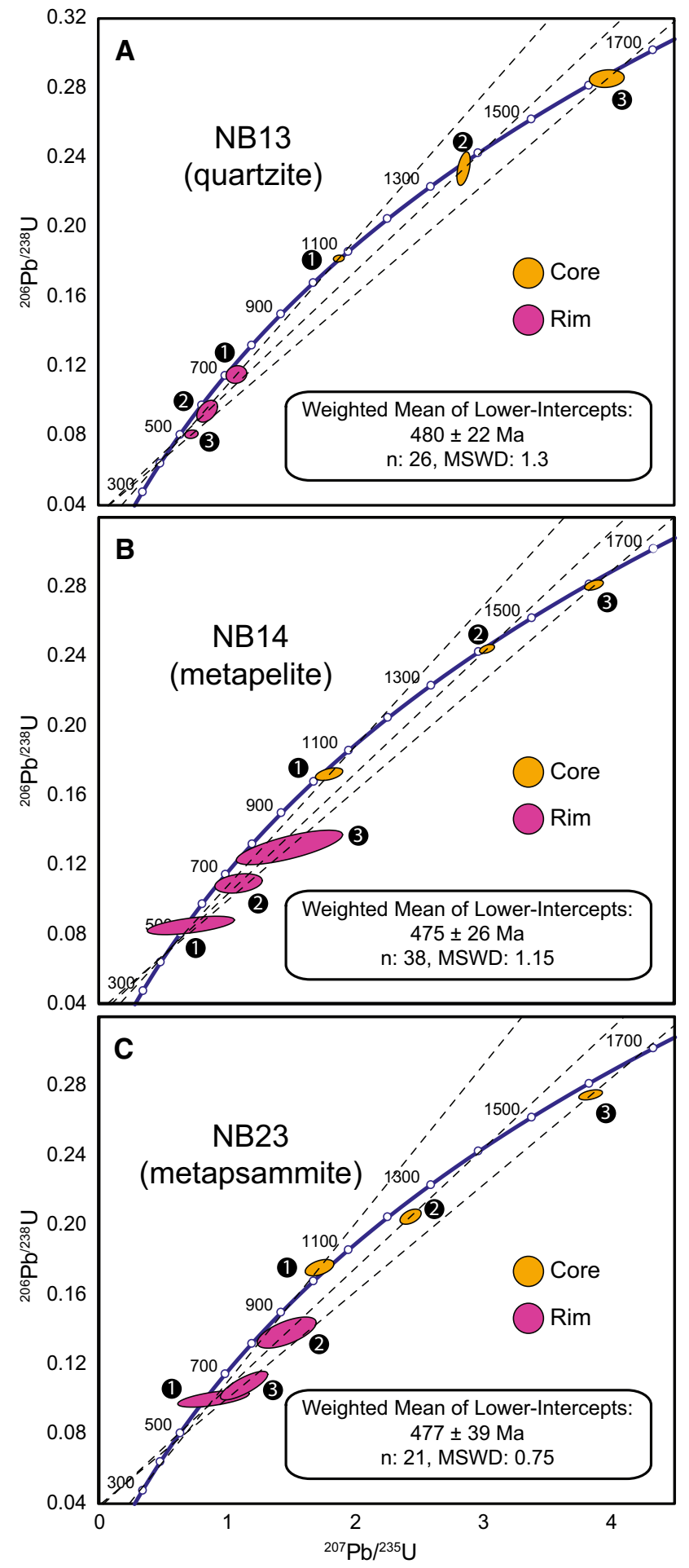

Fig. 8 Wetherill Concordia plots demonstrating our preferred method for calculating the age of zircon rim formation for each sample. Three representative samples are shown for each sample. A single discordance regression line was calculated for a core (yellow ellipse) and rim (purple ellipse) pair for a single grain. The weighted average for the lower intercepts of all core-rim regressions for a single sample was calculated, representing the age of zircon rim formation (presented in the boxes). The large ellipse errors for samples NB14 and NB23 result from the $\mathrm{PbC}$-correction applied to the rim integrations. Datapoint error ellipses are $2 \sigma$. The zircon regressions shown are: NB13-11, NB1318, NB13-61; NB14-4, NB14-25, NB14-35; NB23-12, NB23-40, NB23-71 space for every regression of each individual grain using the core dates. Plotting core dates in Wetherill Concordia required the accurate representation of the ${ }^{207} \mathrm{~Pb} /{ }^{206} \mathrm{~Pb}$ core isotopic ratios as ${ }^{206} \mathrm{~Pb} /{ }^{238} \mathrm{U}$ and ${ }^{207} \mathrm{~Pb} /{ }^{235} \mathrm{U}$ isotopic ratios in Wetherill Concordia space. To achieve this, the discordance of ${ }^{207} \mathrm{~Pb} /{ }^{206} \mathrm{~Pb}$ vs. ${ }^{206} \mathrm{~Pb} /{ }^{238} \mathrm{U}$ and ${ }^{207} \mathrm{~Pb} /{ }^{206} \mathrm{~Pb}$ vs. ${ }^{207} \mathrm{~Pb} /{ }^{235} \mathrm{U}$ ratios was calculated for every individual core integration for each zircon grain (up to four integrations per zircon core; Supplementary Table A3). Only integrations that had $<12 \%$ normal or $<6 \%$ reverse discordance were accepted, preventing large discrepancies between isotopic ratios to propagate into the fixed upper intercept. A weighted average of the ${ }^{206} \mathrm{~Pb} /{ }^{238} \mathrm{U}$ and ${ }^{207} \mathrm{~Pb} /{ }^{235} \mathrm{U}$ ratios for the accepted integrations of each zircon grain was calculated so that the ${ }^{207} \mathrm{~Pb} /{ }^{206} \mathrm{~Pb}$ core ages were appropriately represented in Wetherill Concordia space. The ${ }^{206} \mathrm{~Pb} /{ }^{238} \mathrm{U}$ and ${ }^{207} \mathrm{~Pb} /{ }^{235} \mathrm{U}$ isotopic ratios for the rim analyses were obtained directly from the analyses of Ablation Pit 2. A single regression for each zircon grain was then performed from its fixed upper intercept through the rim analysis. The upper intercept for every core-rim pair was checked against the calculated ${ }^{207} \mathrm{~Pb} /{ }^{206} \mathrm{~Pb}$ core age for that same zircon (Supplementary Table A4). This ensured that the ${ }^{207} \mathrm{~Pb} /{ }^{206} \mathrm{~Pb},{ }^{206} \mathrm{~Pb} /{ }^{238} \mathrm{U}$, and ${ }^{207} \mathrm{~Pb} /{ }^{235} \mathrm{U}$ isotopic ratios all calculated ages that are indistinguishable within error, and therefore, the lower intercept was not biased by an incorrect upper intercept. The method is not affected by discordant core ellipses as long as the upper intercept matches the ${ }^{207} \mathrm{~Pb} /{ }^{206} \mathrm{~Pb}$ date of the core, but the errors of the core integrations are still accounted for in the lower-intercept. A weighted average of the lower intercepts for each sample was then calculated to resolve the timing of zircon rim development. The weighted averages of the lower intercepts are: $480 \pm 22$ (NB13, n: 26, MSWD: 1.3); 475 $\pm 26 \mathrm{Ma}$ (NB14, n: 38, MSWD: 1.15); and $477 \pm 39$ (NB23, n: 21, MSWD: 0.75) (Fig. 8).

\section{Thermometry}

Zircon rims were utilized for Ti-in-Zrn thermometry, using the calibration of Ferry and Watson (2007). The concentrations of $\mathrm{Ti}(\mathrm{ppm})$ were obtained using Iolite software. Integrations of rims and core were defined for every grain. Grains that had rims with anomalously high Ti concentrations (often exceeding $100 \mathrm{ppm}$ ) were discarded to avoid the influence of inclusions or fractures. Additionally, grains with Ti concentrations in the rims that were indistinguishable from the core values were also not considered for calculation of Ti-in-Zrn temperatures. The integrated concentrations of rim analyses ranged from 12 to $23 \mathrm{ppm}$ for all samples, whereas cores ranged from 3 to 13 ppm (Supplementary Table A5). These concentrations correspond to $695-875^{\circ} \mathrm{C}$ (NB13, n: 18), 707-890 ${ }^{\circ} \mathrm{C}$ (NB14, n: 19), 693-892 ${ }^{\circ} \mathrm{C}$ (NB23, n: 28). The temperature ranges incorporate both the 
uncertainty of the calibration and the uncertainty of the rim Ti concentrations.

Thirteen analyses were conducted on rutile inclusions in garnet in sample NB22. The concentration of $\mathrm{Zr}$ ranges from $78 \mathrm{ppm}$ to $263 \mathrm{ppm}$ with an average of $150 \mathrm{ppm}$ (Table A6). Temperatures were calculated according to the pressuredependent calibration of Tomkins et al. (2007). Average temperatures (determined for different pressures) are $594^{\circ} \mathrm{C}$ (10 kbar), $614{ }^{\circ} \mathrm{C}(15 \mathrm{kbar})$ and $635^{\circ} \mathrm{C}(20 \mathrm{kbar})$. We assign an uncertainty of $\pm 30^{\circ} \mathrm{C}$ for the reported values according to the uncertainties discussed by Tomkins et al. (2007).

\section{Discussion}

\section{Timing of events recorded by monazite}

Monazite exhibits four distinct populations based on Th-U-total Pb and geochemical traits (Fig. 4; Supplementary Table A1). The textural relationships of the Neoproterozoic, Group 1 and Group 2 monazite are typical dissolution-reprecipitation features (Fig. 3) as demonstrated by many natural examples (e.g. Finger and Krenn 2007; Holder et al. 2015; Kohn et al. 2005; Williams et al. 2011) and laboratory experiments (e.g. Budzyń et al. 2011, 2017; Harlov et al. 2011; Seydoux-Guillaume et al. 2012; Shazia et al. 2015). No relationship between Group 3 and the other monazite populations are observed.

The Neoproterozoic monazite yields a weighted average of $603 \pm 16 \mathrm{Ma}$ that lies within the range of previous geochronological studies calculating the timing of dyke swarm emplacement, protoliths to eclogite in the Vaimok Lens (Albrecht 2000), at $607 \pm 2 \mathrm{Ma}$ (Root and Corfu 2012) and $608 \pm 1$ Ma in the Sarek Lens (Svenningsen 2001), the latter located $100 \mathrm{~km}$ northeast from our field area. Therefore, from a geochronological standpoint, this monazite may be related to contact metamorphism caused by the emplacement of mafic dykes. However, the patchy zoning texture of the Neoproterozoic domains may indicate partial dissolution of these domains, and the Neoproterozoic Th-U-total $\mathrm{Pb}$ dates may reflect an older crystallization age that was partially reset. As a result, the interpretation of the Neoproterozoic monazite remains equivocal.

Neoproterozoic domains are delimited by a distinct, lobate boundary. The Group 1 analyses are typically located proximal to this boundary, where preserved. Trace elements of Group 1 monazite are indistinguishable from the Neoproterozoic monazite, however, the Group 1 weighted average age of $502 \pm 15 \mathrm{Ma}$ demonstrates Pb-loss during probable dissolution-reprecipitation. Dissolution-reprecipitation of monazite progresses from the grain boundary inwards (Harlov et al. 2011) therefore, it is plausible that the Group 1 domains represent the final stage of dissolution-reprecipitation when $\mathrm{Pb}$ was expelled yet the geochemical composition of the Neoproterozoic domains remained. However, the proximity of the Group 1 analytical spots to the Neoproterozoic domains suggests a degree of analytical mixing for the Group 1 results. It is also possible that Neoproterozoic domains were incompletely dissolved adjacent to the dissolution-reprecipitation interface and remain within the Group 1 domains (Seydoux-Guillaume et al. 2018; Williams et al. 2011). Therefore, we do not attach any geological significance to the Group 1 age of $502 \pm 15 \mathrm{Ma}$.

Dissolution of Neoproterozoic monazite and reprecipitation to form the Group 2 monazite occurred at $498 \pm 10 \mathrm{Ma}$. The decrease in $\mathrm{Y}_{2} \mathrm{O}_{3}$ observed for the Group 2 domains with respect to the Neoproterozoic domains (Fig. 4) demonstrates that garnet was growing in the rock simultaneous to the dissolution-reprecipitation of monazite (e.g. Foster et al. 2000, 2002; Kohn et al. 2005; Rubatto et al. 2013). This is supported by the inclusions of monazite (within garnet) that record a Caledonian $\mathrm{Th}-\mathrm{U}-$ total $\mathrm{Pb}$ signature. The calculated temperature of $594 \pm 30{ }^{\circ} \mathrm{C}$ resulting from $\mathrm{Zr}$ in-Rt thermometry (Tomkins et al. 2007; Zack et al. 2004) conducted on rutile inclusions in garnet provides a minimum temperature estimate for garnet growth in the metasediments. Furthermore, the overall elevated $\mathrm{SrO}$ (wt\%) in the Group 2 domains compared to the Neoproterozoic suggests that $\mathrm{Sr}$ was liberated at the same time as monazite reprecipitation, indicating instability of plagioclase during garnet growth and dissolution-reprecipitation of the monazite (Finger and Krenn 2007; Holder et al. 2015; Krenn and Finger 2004). The broad range of $\mathrm{SrO}$ values could reflect that the availability of $\mathrm{SrO}$ incorporated in monazite was variable through time, or that $\mathrm{SrO}$ incorporation into monazite was controlled by local availability on the grain-scale. Nevertheless, the instability of plagioclase is an indication that dissolution-reprecipitation likely occurred under highpressure conditions (Finger and Krenn 2007; Holder et al. 2015; Krenn and Finger 2004).

A degree of uncertainty exists regarding the confidence of the weighted average ages reported for Group 2 as the $\mathrm{Th}-\mathrm{U}-$ total $\mathrm{Pb}$ dating method cannot distinguish common$\mathrm{Pb}$. Holder et al. (2015) revealed significant concentrations of common- $\mathrm{Pb}$ in monazite which formed via dissolution-reprecipitation of older monazite in UHP conditions. To add further uncertainty, dissolution-reprecipitation experiments coupled with transmission electron microscopy have revealed relic, nano-scale domains of older monazite preserved in the younger, reprecipitated monazite (SeydouxGuillaume et al. 2018). Monazite that grows in sub-UHP conditions, however, typically has little to no incorporation of common- $\mathrm{Pb}$ (Montel et al. 1996). Furthermore, if $\mu \mathrm{m}-\mathrm{nm}$-scale domains of Neoproterozoic material persisted within the reprecipitated monazite domain, we should expect 
such mixing to be reflected not only in the Th-U-total $\mathrm{Pb}$ signature but also in chemistry. The clear distinction between the Neoproterozoic and Group 2 monazite with respect to $\mathrm{Y}_{2} \mathrm{O}_{3}, \mathrm{ThO}_{2}, \mathrm{UO}_{2}$, and $\mathrm{SrO}$ content (Fig. 4) implies that there is probably an insignificant volume of Neoproterozoic monazite, if any, that was incorporated in the reprecipitated domain. We are confident that the weighted average age of $498 \pm 10$ Ma represents the timing of prograde metamorphism of the southern area of the Vaimok Lens because the reprecipitated monazite records prograde garnet growth in the metasediments, reaching high-pressure conditions and previous geochronology constrained eclogite-facies metamorphism at $482 \pm 1 \mathrm{Ma}$ (Root and Corfu 2012).

All four of the analytical points that recorded Group 3 monazite chemistry were located on a single grain. No spatial relationships are recognized with Neoproterozoic/ Group 1 and 2 monazite providing no indication that Group 3 formed via dissolution-reprecipitation of a previous monazite volume. Group 3 domains are distinctly higher in $\mathrm{Y}_{2} \mathrm{O}_{3}$ (wt\%) than any of the other groups (Fig. 4). This elevated $\mathrm{Y}_{2} \mathrm{O}_{3}$ content would suggest new monazite growth during partial garnet dissolution (e.g. Foster and Parrish 2003; Kelly et al. 2006; Mahan et al. 2006; McFarlane et al. 2005).

\section{Timing of events recorded by zircon}

Xenocrystic zircon cores analyzed in this study preserve REE patterns typical for igneous zircon (Hoskin and Ireland 2000; Hoskin and Schaltegger 2001) and their integrated $\mathrm{U}-\mathrm{Pb}$ dates range from Neoproterozoic to Paleoproterozoic with minor Archean input for all samples (Fig. 7), strongly indicative of detrital populations. The ${ }^{207} \mathrm{~Pb} /{ }^{206} \mathrm{~Pb}$ detrital zircon spectra for each sample highlight patterns that are typical for sediments of the Grapesvare Nappe (SNC; Fig. 2) and associated nappes (see Gee et al. 2015). Backscattered electron images of zircon cross-sections reveal concave-inwards BSE-bright zones coupled with $\mu \mathrm{m}$-scale pores, typical for dissolution-reprecipitation structures of zircon (Fig. 5; Geisler et al. 2007; Harley et al. 2007; Putnis 2009; Rubatto et al. 2008). The majority of zircon rims from the Vaimok Lens show enrichments in trace elements with respect to the zircon core. The rims of all samples are enriched in LREE, U, Th (Fig. 6). Samples NB14 and NB23 also show coupled enrichment in P, Sr, and $\mathrm{Y}$. Whereas $\mathrm{U}, \mathrm{Th}$, and $\mathrm{P}$ can be incorporated in zircon, LREE do not fit into the zircon crystal structure and enrichment could reflect $\mu \mathrm{m}-\mathrm{nm}$-scale inclusions in the zircon rims (Geisler et al. 2007). Weighted averages of the lowerintercepts derived from discordance regression of zircon rim-core pairs yield ages of $480 \pm 22$ (NB13), $475 \pm 26 \mathrm{Ma}$ (NB14), and $477 \pm 39$ (NB23), interpreted as the ages of zircon rim dissolution-reprecipitation (Fig. 8). However, the significant uncertainty of the ${ }^{204} \mathrm{~Pb}$ measurement applied to the ${ }^{204} \mathrm{~Pb}$-correction propagated into the lower-intercept weighted averages. The uncertainty encompasses much of the timescale of subduction and prograde metamorphism, to peak metamorphism (482 $\pm 1 \mathrm{Ma}$; Root and Corfu 2012), and exhumation/retrogression of the Vaimok Lens. As a result, the geochronological results must be interpreted in conjunction with the geochemistry of the zircon rims to reveal at which stage of the subduction-exhumation cycle the dissolution-reprecipitation of the zircon rims occurred.

The elements incorporated into the zircon rims (LREE, $\mathrm{P}, \mathrm{Th}, \mathrm{U}, \pm \mathrm{Y}, \pm \mathrm{Sr}$ ) strongly resemble the chemistry of monazite. This suggests that dissolution-reprecipitation of the zircon rims is connected to physiochemical processes affecting monazite, as either (1) dissolution-reprecipitation of monazite during subduction; or (2) breakdown of monazite to form apatite, allanite and clinozoisite during exhumation. Coupled dissolution-reprecipitation of monazite and zircon in our rocks could be a plausible means of liberating trace elements from monazite and uptaking them into the zircon rims. The dissolution-reprecipitation of monazite in our rocks records the growth of garnet (i.e. depletion in $\mathrm{Y}_{2} \mathrm{O}_{3}$ with respect to the Neoproterozoic cores). If dissolution-reprecipitation of zircon rims was coeval with this monazite recrystallization, then the zircon rims should be depleted in HREE as the growth of garnet sequesters HREE (Bingen et al. 2004; Hermann and Rubatto 2003; Kohn and Kelly 2018; Rubatto 2002, 2017; Rubatto and Hermann 2007; Whitehouse and Platt 2003). However, zircon rims show little to no change in HREE content (Fig. 6; Supplementary Table A2) suggesting that the zircon rims did not form during garnet growth, and therefore, are likely not related to dissolution-reprecipitation of monazite.

The alternative is that monazite breakdown to form apatite, allanite and clinozoisite supplied the trace elements that were incorporated in the zircon rims (Fig. 9). Both prograde (low $\mathrm{Y}_{2} \mathrm{O}_{3}$ monazite) and retrograde monazite (high $\mathrm{Y}_{2} \mathrm{O}_{3}$ ) experienced such reaction with the clinozoisite coronas typically aligned parallel to the retrogressive 'S2 foliation' (Albrecht 2000). Furthermore, results of Tiin-Zrn thermometry indicate that zircon rims formed in temperatures $>700{ }^{\circ} \mathrm{C}$, whereas the low-Eu anomalies of the rims (with respect to the cores) indicate rim formation under high-pressure conditions (Bingen et al. 2004; Kohn and Kelly 2018; Rubatto 2002, 2017; Rubatto and Hermann 2007; Whitehouse and Platt 2003). These conditions are comparable to peak temperatures of $\sim 735{ }^{\circ} \mathrm{C}$ (at $2.1 \mathrm{GPa}$ ) experienced by the Vaimok Lens eclogite assemblages during decompression (i.e. the E3 stage of Bukała et al. 2018). The E3 stage of Bukała et al. (2018) records an influx of Carich fluid into the Vaimok Lens, which could catalyze monazite breakdown to apatite, allanite and clinozoisite (Budzyń et al. 2011). Dissolution-reprecipitation of zircon rims was likely facilitated by this Ca-rich fluid and was coeval with 

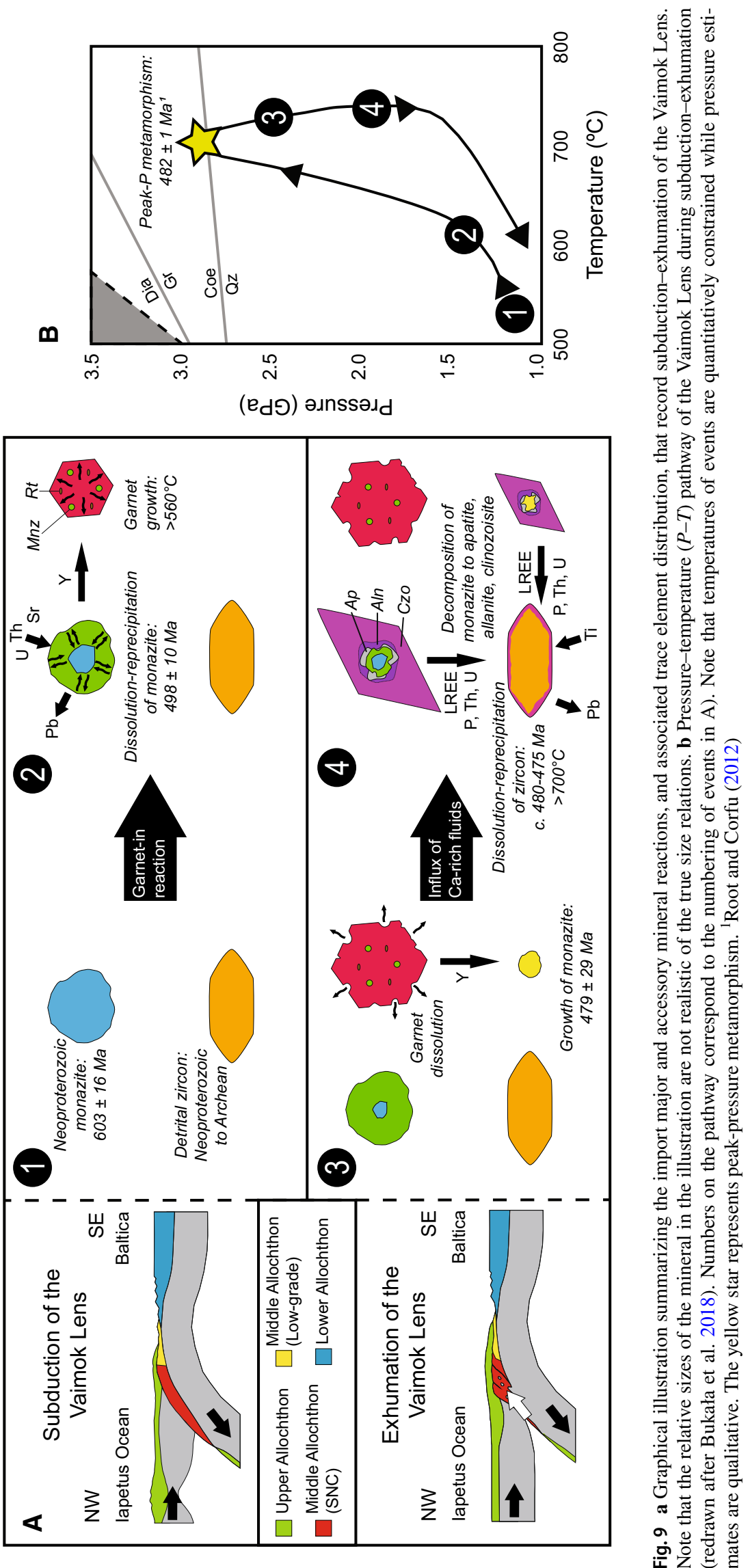
the breakdown of monazite to apatite, allanite and clinozoisite during initial exhumation of the Vaimok Lens.

\section{Subduction-exhumation of the Vaimok Lens}

The robust nature of both monazite and zircon geochronometers allowed for the preservation of the timing record of subduction and initial exhumation of the Vaimok Lens (Fig. 9). Monazite with a Neoproterozoic Th-U-total $\mathrm{Pb}$ signature and Neoproterozoic to Archean igneous zircon grains were able to survive through Caledonian subduction and associated prograde metamorphism, attaining high-pressure conditions. The survival of zircon through such conditions is typical, whereas natural, experimental and numerical studies predict that monazite should react to form allanite in medium-grade conditions (e.g. Budzyń et al. 2011; Janots et al. 2007; Smith and Barreiro 1990; Spear 2010; Wing et al. 2003).

In the rocks from the Vaimok Lens, there is no evidence for the existence of prograde allanite and Neoproterozoic monazite is observed to be the direct precursor of the reprecipitated high-pressure Cambrian monazite. Previous studies of natural samples have also reported similar observations for monazite (e.g. Finger and Krenn 2007; Holder et al. 2015; Kohn et al. 2005; Lo Pò et al. 2016; Petrík and Konečný 2009; Williams et al. 2011) indicating that high-pressure monazite does not always require an allanite precursor, which may be instead controlled by bulk rock composition (Spear 2010). We consider that the Neoproterozoic monazite remained (meta)stable in the Vaimok Lens metasediments until the initiation of the garnet growth reactions. Fluids that possibly originated due to this reaction may have triggered the dissolution of the metastable Neoproterozoic monazite and reprecipitated new monazite at $498 \pm 10 \mathrm{Ma}$ (Fig. 9). The stable, reprecipitated monazite recorded both garnet growth (decrease of $\mathrm{Y}_{2} \mathrm{O}_{3}$ ) and highpressure conditions (increase of $\mathrm{SrO}$ ). The high-pressure conditions coupled with the minimum temperature of garnet growth at $594 \pm 30{ }^{\circ} \mathrm{C}$ suggests that the metasedimentary rocks of the Vaimok Lens underwent a similar $P-T$ path as the eclogites they are hosting. Peak-pressure metamorphism for the Vaimok Lens of 2.8-3.1 GPa at $\sim 700{ }^{\circ} \mathrm{C}$ (Bukała et al. 2018) was attained at $482 \pm 1 \mathrm{Ma}$ (Root and Corfu 2012). The reprecipitated Caledonian monazite (Group 2) remained undisturbed through peak-pressure metamorphism. Minor monazite growth (Group 3) occurred during initial decompression dissolution of garnet at $479 \pm 29 \mathrm{Ma}$.

As exhumation continued, peak temperature conditions of $\sim 2.1 \mathrm{GPa}$ at $\sim 735{ }^{\circ} \mathrm{C}$ (Bukała et al. 2018) were attained, coinciding with the influx of Ca-rich fluids into the Vaimok Lens, likely from the underlying continental rocks that were still subducting and undergoing devolatilization (Bukała et al. 2018). Until this point, monazite was a stable phase in the metasediments, however, the influx of Ca-rich fluid destabilized monazite, aiding the formation apatite, allanite and clinozoisite. This reaction has previously been documented in high-pressure rocks (Gabudianu Radulescu et al. 2009) and during decompression (Lo Pò et al. 2016). The destabilization of monazite in the Vaimok Lens metasediments is recorded in the reprecipitated zircon rims that formed at $480 \pm 22$ (NB13), $475 \pm 26 \mathrm{Ma}$ (NB14), and $477 \pm 39$ (NB23). The Eu-anomalies of the zircon rims indicate dissolution-reprecipitation of the xenocrystic cores occurred under high-pressure conditions and temperatures $>700{ }^{\circ} \mathrm{C}$ (Fig. 9), similar to the stage-E3 conditions of Bukała et al. (2018).

The new geochronological results are consistent with the c. 482 Ma timing of eclogite-facies metamorphism (Root and Corfu 2012) and strengthen the interpretations of Essex et al. (1997) that prograde metamorphism (i.e. subduction) occurred in the late Cambrian in the Vaimok Lens. Our results together with the results of Root and Corfu (2012) indicate that previously reported dates documenting peak metamorphism at $503 \pm 14 \mathrm{Ma}$ (Mørk et al. 1988) followed by exhumation at $491 \pm 8 \mathrm{Ma}$ (Dallmeyer and Gee 1986) do not represent the timing of subduction-exhumation for the Vaimok Lens. With these new results, the prograde to peak metamorphic history of the Vaimok Lens is better resolved, and is clearly older than peak-pressure metamorphism farther south in Jämtland at c. 458-460 Ma (Brueckner and van Roermund 2007; Brueckner et al. 2004; Fassmer et al. 2017; Majka et al. 2012). Furthermore, the monazite ages documenting subduction are similar to previous studies of arc volcanism in the Köli Nappe (Upper Allochthon) at $492 \pm 1 \mathrm{Ma}$ (Claesson et al. 1988) and $488 \pm 5 \mathrm{Ma}$ (Claesson et al. 1983), providing a direct geochronological link between subduction of the SNC and arc-volcanism in the overriding plate (Köli Nappe). The results of the decompressional growth of monazite domains and zircon rims indicate that exhumation of the Vaimok Lens likely initiated before peak-pressure metamorphism was realized further south in Jämtland.

The non-synchronicity of the timing of subduction along the SNC is an indication that the geometry of the subduction zone was complex along strike of the orogeny. This leads to several possibilities to explain late Cambrian subduction of the Vaimok Lens, including: (1) a separate subduction zone for the Vaimok Lens than the subduction system recorded further south in Jämtland, (2) the Vaimok Lens represents the introduction of a continental crust promontory into the subduction zone (e.g. Bukała et al. 2018), or (3) a "zipper-geometry" for introduction of continental crust into the subduction zone (akin to subduction under the Sunda-Banda Arc; e.g. Harris 2011; Hamilton 1979), with continental crust introduced progressively from north to south. To resolve these possible models, further geochronological studies need to focus on SNC 
subduction-exhumation processes, especially with attention to the understudied, northern SNC localities. Nevertheless, the results of this study build a foundation for understanding the dynamics of SNC subduction along strike of the orogen.

\section{Conclusions}

We report new monazite and zircon geochemistry and geochronology that records high-pressure subduction and exhumation of the Vaimok Lens metasediments, following a similar $P-T$ path as the eclogitic bodies that they host. Dissolution-reprecipitation of monazite at $498 \pm 10$ Ma records garnet growth in high-pressure conditions at $>560{ }^{\circ} \mathrm{C}$. The monazite preserved their prograde record through subsequent eclogite facies (2.6-2.7 GPa and $\left.680-780{ }^{\circ} \mathrm{C}\right)$, retrogressive metamorphism and associated deformation. Minor monazite growth contemporaneous with incipient exhumation occurred at $479 \pm 29 \mathrm{Ma}$, related to decompression-related dissolution of garnet. As exhumation proceeded, an influx of Ca-rich fluids into the metasediments destabilized monazite, causing it to decompose to apatite, allanite and clinozoisite and facilitate dissolution-reprecipitation of zircon rims. Zircon rim formation recording monazite-breakdown occurred in high-pressure conditions and in temperatures $>690{ }^{\circ} \mathrm{C}$. The interplay between prograde and retrograde metamorphic reactions, and re-distribution of trace elements coupled with dissolution-reprecipitation of accessory phases illustrates the importance of understanding trace element distribution dynamics to record metamorphic events. These results also demonstrate that the application of high spatial resolution techniques applied to accessory minerals (i.e. in situ monazite geochronology and zircon depth-profiling) can successfully extract reliable and consistent geological histories from mineral volumes on the few $\mu \mathrm{m}$-scale.

Acknowledgements This study was funded by the National Science Centre, Poland (CALSUB Project no. 2014/14/E/ST10/00321). We would like to thank Chris McFarlane (University of New Brunswick) for assistance in the laboratory for zircon depth-profiling. Brandon Boucher (University of New Brunswick) is especially thanked for his time, effort and patience in dealing with managing and organization of the zircon data, and for teaching the ways of the Iolite software. We would also like to thank Patrik Konečný for his assistance in the laboratory for $\mathrm{Th}-\mathrm{U}-$ total $\mathrm{Pb}$ dating of monazite. Adam Włodek is thanked for helping with the electron microprobe investigations. Daniela Rubatto is gratefully thanked for her editorial handling and comments. We also thank Chris Mattinson and Robert Holder for their reviews, comments, and constructive criticisms.

Open Access This article is distributed under the terms of the Creative Commons Attribution 4.0 International License (http://creativeco mmons.org/licenses/by/4.0/), which permits unrestricted use, distribution, and reproduction in any medium, provided you give appropriate credit to the original author(s) and the source, provide a link to the Creative Commons license, and indicate if changes were made.

\section{References}

Albrecht L (2000) Early structural and metamorphic evolution of the Scandinavian Caledonides a study of the eclogite-bearing Seve Nappe Complex at the Arctic Circle, Sweden. PhD Dissertation, Lund University

Andréasson PG, Gee DG, Sukotji S (1985) Seve eclogites in the Norrbotten Caledonides, Sweden. In: Gee DG, Sturt BA (eds) The Caledonide Orogen-Scandinavia and related areas. Wiley, Oxford, pp 887-902

Bingen B, Austrheim H, Whitehouse MJ, Davis WJ (2004) Trace element signature and $\mathrm{U}-\mathrm{Pb}$ geochronology of eclogite-facies zircon, Bergen Arcs, Caledonides of W Norway. Contrib Mineral Pet 147:671-683. https://doi.org/10.1007/s00410-004-0585-z

Breeding CM, Ague JJ, Grove M, Rupke AL (2004) Isotopic and chemical alteration of zircon bt metamorphic fluids: $\mathrm{U}-\mathrm{Pb}$ age depthprofiling of zircon crystals from Barrow's garnet zone, northeast Scotland. Am Mineral 89:1067-1077

Broska I, Williams CT, Janák M, Nagy G (2005) Alteration and breakdown of xenotime-(Y) and monazite-(Ce) in granitic rocks of the Western Carpathians. Slovakia Lithos 82:71-83

Brueckner HK, van Roermund HLM (2004) Dunk tectonics: a multiple subduction/eduction model for the evolution of the Scandinavian Caledonides. Tectonics 23:1-20. https://doi.org/10.1029/2003T C001502

Brueckner HK, van Roermund HLM (2007) Concurrent HP metamorphism on both margins of Iapetus: ordovician ages for eclogites and garnet pyroxenites from the Seve Nappe Complex, Swedish Caledonides. J Geol Soc London 164:117-128

Brueckner HK, Van Roermund HLM, Pearson N (2004) An Archean to Paleozoic evolution for a garnet peridotite lends with sub-Baltic Shield affinity within the Seve Nappe Complex of Jämtland, Sweden, Central Scandinavian Caledonides. J Petrol 43:415-437

Budzyń B, Harlov DE, Williams ML, Jercinovic MJ (2011) Experimental determination of stability relations between monazite, fluorapatite, allanite, and REE-epidote as a function of pressure, temperature, and fluid composition. Am Mineral 96:1547-1567. https://doi.org/10.2138/am.2011.3741

Budzyń B, Harlov DE, Kozub-Budzyn GA, Majka J (2017) Experimental constraints on the relative stabilities of the two systems monazite-(Ce)-allanite-(Ce)-fluorapatite and xenotime-(Y)(Y,HREE)-rich epidote-(Y,HREE)-rich fluorapatite, in high Ca and $\mathrm{Na}-\mathrm{Ca}$ environments under P-T conditions of 200-1000 $\mathrm{MPa}$ and $450-750{ }^{\circ} \mathrm{C}$. Mineral Petrol 111:183-217. https://doi. org/10.1007/s00710-016-0464-0

Bukała M, Klonowska I, Barnes C et al (2018) UHP metamorphism recorded by phengite eclogite from the Caledonides of northern Sweden: P-T path and tectonic implications. J Metamorph Geol. https://doi.org/10.1111/jmg.12306

Claesson S, Klingspor I, Stephens MB (1983) U-Pb and Rb-Sr isotopic data on an Ordovician volcanic-subvolcanic complex from the Tjopasi group, Köli nappes, Swedish Caledonides. Gff 105:9-15. https://doi.org/10.1080/11035898309455285

Claesson S, Stephens MB, Klingspor I (1988) U-Pb zircon dating of felsic intrusions, Middle Koli Nappes, central Scandinavian Caledonides (Sweden). Nor Geol Tidsskr 68:89-97

Dallmeyer RD, Gee DG (1986) ${ }^{40} \mathrm{Ar} /{ }^{39} \mathrm{Ar}$ mineral dates from retrogressed eclogites within the Baltoscandian miogeocline: implications for a polyphase Caledonian orogenic evolution. Geol Soc Am Bull 97:26-34

Engi M (2017) Petrochronology based on REE-minerals: monazite, allanite, xenotime, apatite. Rev Mineral Geochem 83:365-408

Essex RM, Gromet LP, Andreasson P-G, Albrecht L (1997) Early Ordovician $\mathrm{U}-\mathrm{Pb}$ metamorphic ages of the eclogite-bearing Seve 
Nappes, Northern Scandinavian Caledonides. J Metamorph Geol 15:665-676

Fassmer K, Klonowska I, Walczak K et al (2017) Middle Ordovician subduction of continental crust in the Scandinavian Caledonides: an example from Tjeliken, Seve Nappe Complex, Sweden. Contrib Mineral Pet 172:1-21

Ferry JM, Watson EB (2007) New thermodynamic models and revised calibrations for the Ti-in-zircon and Zr-in-rutile thermometers. Contrib Mineral Pet 154:429-437. https://doi.org/10.1007/s0041 0-007-0201-0

Finger F, Krenn E (2007) Three metamorphic monazite generations in a high-pressure rock from the Bohemian Massif and the potentially important role of apatite in stimulating polyphase monazite growth along a PT loop. Lithos 95:103-115. https://doi. org/10.1016/j.lithos.2006.06.003

Finger F, Broska I, Roberts MP, Schermaier A (1998) Replacement of primary monazite by apatite-allanite-epidote coronas in an amphibolite facies granite gneiss from the eastern Alps. Am Min $83: 248-258$

Foster G, Parrish RR (2003) Metamorphic monazite and the generation of P-T-t paths. Geol Soc Lond Spec Publ 220:25-47. https://doi. org/10.1144/GSL.SP.2003.220.01.02

Foster G, Kinny P, Vance D et al (2000) The significance of monazite $\mathrm{U}-\mathrm{Th}-\mathrm{Pb}$ age data in metamorphic assemblages; a combined study of monazite and garnet chronometry. Earth Planet Sci Lett 181:327-340

Foster G, Gibson HD, Parrish R, Horstwood M, Fraser J, Tindle A (2002) Textural, chemical and isotopic insights into the nature and behavior of metamorphic monazite. Chem Geol 191:183-207

Gabudianu Radulescu I, Rubatto D, Gregory C, Compagnoni R (2009) The age of HP metamorphism in the Gran Paradiso Massif, Western Alps: a petrological and geochronological study of "silvery micaschists". Lithos 110:95-108. https://doi.org/10.1016/j.litho s.2008.12.008

Gee DG, Ladenberger A, Dahlqvist P et al (2013) The Baltoscandian margin detrital zircon signatures of the central Scandes. Geol Soc Lond Spec Publ 390:131-155. https://doi.org/10.1144/SP390.20

Gee DG, Andréasson P-G, Lorenz H et al (2015) Detrital zircon signatures of the Baltoscandian margin along the Arctic Circle Caledonides in Sweden: the Sveconorwegian connection. Precambrian Res 265:40-56. https://doi.org/10.1016/j.precamres.2015.05.012

Geisler T, Schaltegger U, Tomaschek F (2007) Re-equilibration of zircon in aqueous fluids and melts. Elements 3:43-50

Gilio M, Clos F, van Roermund HLM (2015) The Friningen Garnet Peridotite (central Swedish Caledonides). A good example of the characteristic PTt path of a cold mantle wedge garnet peridotite. Lithos 230:1-16. https://doi.org/10.1016/j.lithos.2015.05.003

Hamilton W (1979) Tectonics of the Indonesian region. US Geol Surv Prof Pap 1078:1-345

Harley SL, Kelly NM, Möller A (2007) Zircon behaviour and the thermal histories of mountain chains. Elements 3:25-30. https://doi. org/10.2113/gselements.3.1.25

Harlov DE, Wirth R, Hetherington CJ (2011) Fluid-mediated partial alteration in monazite: the role of coupled dissolution-reprecipitation in element redistribution and mass transfer. Contrib Mineral Pet 162:329-348. https://doi.org/10.1007/s00410-010-0599-7

Harris R (2011) The nature of the Banda arc-continent collision in the Timor region. In: Brown D, Ryan PD (eds) Arc continent collision. Springer, Berlin, pp. 163-211

Hermann J, Rubatto D (2003) Relating zircon and monazite domains to garnet growth zones: age and duration of granulite facies metamorphism in the Val Malenco lower crust. J Metamorph Geol 21:833-852. https://doi.org/10.1046/j.1525-1314.2003.00484.x

Holder RM, Hacker BR, Kylander-Clark ARC, Cottle JM (2015) Monazite trace-element and isotopic signatures of (ultra) high-pressure metamorphism: examples from the Western Gneiss Region, Norway. Chem Geol 409:99-111

Hoskin PWO, Ireland TR (2000) Rare earth element chemistry of zircon and its use as a provenance indicator. Geology 28:627-630

Hoskin PWO, Schaltegger U (2001) The composition of zircon and igneous and metamorphic petrogenesis. Rev Mineral Geochem 53:27-62

Janák M, Van Roermund H, Majka J, Gee D (2013) UHP metamorphism recorded by kyanite-bearing eclogite in the Seve Nappe Complex of northern Jämtland, Swedish Caledonides. Gondwana Res 23:865-879. https://doi.org/10.1016/j.gr.2012.06.012

Janots E, Brunet F, Goffe B et al (2007) Thermochemistry of monazite-(La) and dissakisite-(La): implications for monazite and allanite stability in metapelites. Contrib Mineral Pet 154:1-14. https://doi.org/10.1007/s00410-006-0176-2

Kelly NM, Clarke GL, Harley SL (2006) Monazite behaviour and age significance in poly-metamorphic high-grade terrains: a case study from the western Musgrave Block, central Australia. Lithos 88:100-134. https://doi.org/10.1016/j.lithos.2005.08.007

Kelly CJ, McFarlane CRM, Schneider DA, Jackson SE (2014) Dating micrometre-thin rims using a LA-ICP-MS depth profiling technique on zircon from an archaean metasediment: comparison with the SIMS depth profiling method. Geostand Geoanal Res 38:389-407. https://doi.org/10.1111/j.1751-908X.2014.00314.x

Kelly CJ, Schneider DA, Kalbfleisch T, Jackson S, McFarlane C (2017) Insights into the alkaline alteration of zircon: depthprofile techniques and unpolished grain mapping. Chem Geol 449:82-98. https://doi.org/10.1016/j.chemgeo.2016.11.035

Klonowska I, Majka J, Janak M et al (2014) Pressure-temperature evolution of a kyanite-garnet pelitic gneiss from Areskutan: evidence of ultra-high-pressure metamorphism of the Seve Nappe Complex, west-central Jamtland, Swedish Caledonides. Geol Soc Lond Spec Publ 390 390:321-336. https://doi.org/10.1144/ SP390.7

Klonowska I, Janák M, Majka J et al (2016) Eclogite and garnet pyroxenite from Stor Jougdan, Seve Nappe Complex, Sweden: implications for UHP metamorphism of allochthonous in the Scandinavian Caledonides. J Metamorph Geol 34:103-119. https://doi. org/10.1111/jmg. 12173

Klonowska I, Janak M, Majka J et al (2017) Microdiamond on Areskutan confirms regional UHP metamorphism in the Seve Nappe Complex of the Scandinavian Caledonides. J Metamorph Geol 35:541-564. https://doi.org/10.1111/jmg.12244

Kohn MJ, Kelly NM (2018) Petrology and geochronology of metamorphic zircon. In: Moser DE, Corfu F, Darling JR, Reddy SM, Tait $\mathrm{K}$ (eds) Microstructural geochronology: planetary records down to atom scale. Wiley, Oxford, pp 35-61

Kohn MJ, Wieland MS, Parkinson CD, Upreti BN (2005) Five generations of monazite in Langtang gneisses: implications for chronology of the Himalayan metamorphic core. J Metamorph Geol 23:399-406. https://doi.org/10.1111/j.1525-1314.2005.00584.x

Konečný P, Kusiak MA, Dunkley DJ (2018) Improving U-Th-Pb electron microprobe dating using monazite age references. Chem Geol 484:22-35. https://doi.org/10.1016/j.chemgeo.2018.02.014

Krenn E, Finger F (2004) Metamorphic formation of Sr-apatite and Sr-bearing monazite in a high-pressure rock from the Bohemian Massif. Am Mineral 89:1323-1329

Krenn E, Ustaszewski K, Finger F (2008) Detrital and newly formed metamorphic monazite in amphibolite-facies metapelites from the Motajica Massif, Bosnia. Chem Geol 254:164-174. https://doi. org/10.1016/j.chemgeo.2008.03.012

Kullerud K, Stephens MB, Zachrisson E (1990) Pillow lavas as protoliths for eclogites: evidence from a late Precambrian-Cambrian continental margin, Seve Nappes, Scandinavian Caledonides. Contrib Mineral Pet 105:1-10 
Lo Pò D, Braga R, Massone H-J, Molli G, Montanini A, Theye T (2016) Fluid-induced breakdown of monazite in medium-grade metasedimentary rocks of the Pontremoli basement (Northern Apennines, Italy). J Metamorph Geol 34:63-84. https://doi. org/10.1111/jmg. 12171

Mahan KH, Goncalves P, Williams ML, Jercinovic MJ (2006) Dating metamorphic reactions and fluid flow: application to exhumation of high-P granulites in a crustal-scale shear zone, western Canadian Shield. J Metamorph Geol 24:193-217. https://doi.org/10.1 111/j.1525-1314.2006.00633.x

Majka J, Be'eri-Shlevin Y, Gee DG et al (2012) Multiple monazite growth in the Areskutan migmatite: evidence for a polymetamorphic Late Ordovician to Late Silurian evolution in the Seve Nappe Complex of west-central Jämtland, Sweden. J Geosci 57:3-23. https://doi.org/10.3190/jgeosci.112

Majka J, Rosén Å, Janák M et al (2014) Microdiamond discovered in the Seve Nappe (Scandinavian Caledonides) and its exhumation by the "vacuum-cleaner" mechanism. Geology 42:1107-1110. https://doi.org/10.1130/G36108.1

Marsh JH, Stockli DF (2015) Zircon U-Pb and trace element zoning characteristics in an anatectic granulite domain: insights from LASS-ICP-MS depth profiling. Lithos 239:170-185

McFarlane C, Luo Y (2012) U-Pb geochronology using 193 nm Excimer LA-ICP-MS optimized for in situ accessory mineral dating in thin sections. Geosci Can 39:158-172

McFarlane CRM, Connelly JN, Carlson WD (2005) Monazite and xenotime petrogenesis in the contact aureole of the Makhavinekh Lake Pluton, northern Labrador. Contrib Mineral Pet 148:524541. https://doi.org/10.1007/s00410-004-0618-7

Montel J-M, Foret S, Veschambre M et al (1996) Electron microprobe dating of monazite. Chem Geol 131:37-53. https://doi. org/10.1016/0009-2541(96)00024-1

Mørk MBE, Kullerud K, Stabel A (1988) Sm-Nd dating of Seve eclogites, Norrbotten, Sweden-evidence for early Caledonian (505 Ma) subduction. Contrib Mineral Pet 99:344-351. https://doi. org/10.1007/BF00375366

Paces JB, Miller JD Jr (1993) Precise U-Pb ages of duluth complex and related mafic intrusions, northeastern minnesota' geochronological insights to physical, petrogenetic, paleomagnetic, and tectonomagmatic processes associated with the 1.1 ga midcontinent rift system. J Geophys Res Solid Earth 98:13997-14013

Paton C, Hellstrom J, Paul B et al (2011) Iolite: freeware for the visualisation and processing of mass spectrometric. J Anal At Spectrom 26:2508-2518. https://doi.org/10.1039/C1JA10172B

Petrík I, Konečný P (2009) Metasomatic replacement of inherited metamorphic monazite in a biotite-garnet granite from Nizke Tatry Mountains, Western Carpathians, Slovakia: chemical dating and evidence for disequilibrium melting. Am Mineral 94:957-974

Petrus JA, Kamber BS (2012) VizualAge: a novel approach to laser ablation ICP-MS U-Pb geochronology data reduction. Geostand Geoanal Res 36:247-270

Putnis A (2009) Mineral replacement reactions. Rev Mineral Geochem 70:87-124. https://doi.org/10.2138/rmg.2009.70.3

Pyle JM, Spear FS, Cheney JT, Layne G (2005) Monazite ages in the Chesham Pond Nappe, SW New Hampshire, U.S.A.: implications for assembly of central New England thrust sheets. Am Mineral 90:592-606. https://doi.org/10.2138/am.2005.1341

Root D, Corfu F (2012) U-Pb geochronology of two discrete Ordovician high-pressure metamorphic events in the Seve Nappe Complex, Scandinavian Caledonides. Contrib Mineral Pet 163:769788. https://doi.org/10.1007/s00410-011-0698-0

Rubatto D (2002) Zircon trace element geochemistry: partitioning with garnet and the link between $\mathrm{U}-\mathrm{Pb}$ ages and metamorphism. Chem Geol 184:123-138. https://doi.org/10.1016/S0009-2541(01)00355 $-2$
Rubatto D (2017) Zircon: the metamorphic mineral. Rev Mineral Geochem 83:261-289

Rubatto D, Hermann J (2003) Zircon formation during fluid circulation in eclogites (Monviso, Western Alps): implications for $\mathrm{Zr}$ and Hf budget in subduction zones. Geochim Cosmochim Acta 67:2173-2187. https://doi.org/10.1016/S0016-7037(02)01321-2

Rubatto D, Hermann J (2007) Experimental zircon/melt and zircon/ garnet trace element partitioning and implications for the geochronology of crustal rocks. Chem Geol 241:38-61. https://doi. org/10.1016/j.chemgeo.2007.01.027

Rubatto D, Williams IS, Buick IS (2001) Zircon and monazite response to prograde metamorphism in the Reynolds Range, central Australia. Contrib Mineral Pet 458-468

Rubatto D, Muntener O, Barnhoorn A, Gregory C (2008) Dissolutionreprecipitation of zircon at low-temperature, high-pressure conditions (Lanzo Massif, Italy). Am Mineral 93:1519-1529. https:// doi.org/10.2138/am.2008.2874

Rubatto D, Chakraborty S, Dasgupta S (2013) Timescales of crustal melting in the Higher Himalayan Crystallines (Sikkim, Eastern Himalaya) inferred from trace element-constrained monazite and zircon chronology. Contrib Mineral Petrol 165:349-372

Santallier DS (1988) Mineralogy and crystallization of the Seve eclogites in the Vuoggatjålme area, Swedish Caledonides of Norrbotten. GFF 110:89-98. https://doi.org/10.1080/11035898809452646

Schneider DA, Senkowski C, Vogel H et al (2011) Eocene tectonometamorphism on Serifos (western Cyclades) deduced from zircon depth-profiling geochronology and mica thermochronology. Lithos 125:151-172. https://doi.org/10.1016/j.lithos.2011.02.005

Seydoux-Guillaume A-M, Montel J-M, Bingen B, Bosse V, de Parseval P, Paquette J-L, Janots E, Wirth R (2012) Low-temperature alteration of monazite: fluid mediated coupled dissolution-precipitation, irradiation damage, and disturbance of the $\mathrm{U}-\mathrm{Pb}$ and $\mathrm{Th}-\mathrm{Pb}$ chronometers. Chem Geol 330-331:140-158

Seydoux-Guillaume A-M, Bingen B, Bosse V, Janots E, Laurent AT (2018) Transmission electron microscope imaging sharpens geochronological interpretation of zircon and monazite. In: Moser DE, Corfu F, Darling JR, Reddy SM, Tait K (eds) Microstructural geochronology: planetary records down to atom scale. Wiley, Oxford, pp 261-276. https://doi.org/10.1002/9781119227250. ch12

Shazia JR, Harlov DE, Suzuki K et al (2015) Linking monazite geochronology with fluid infiltration and metamorphic histories: nature and experiment. Lithos 236-237:1-15. https://doi. org/10.1016/j.lithos.2015.08.008

Skipton DR, Schneider DA, McFarlane CRM et al (2016) Multi-stage zircon and monazite growth revealed by depth profiling and in situ $\mathrm{U}-\mathrm{Pb}$ geochronology: resolving the Paleoproterozoic tectonics of the Trans-Hudson Orogen on southeastern Baffin Island, Canada. Precambrian Res 285:272-298. https://doi.org/10.1016/j.preca mres.2016.09.002

Sláma J, Košler J, Condon DJ et al (2008) Plešovice zircon-a new natural reference material for $\mathrm{U}-\mathrm{Pb}$ and $\mathrm{Hf}$ isotopic microanalysis. Chem Geol 249:1-35. https://doi.org/10.1016/j.chemg eo.2007.11.005

Smith HA, Barreiro B (1990) Monazite U-Pb dating of staurolite grade metamorphism in pelitic schists. Contrib Mineral Pet 105:602-615

Spear FS (2010) Monazite-allanite phase relations in metapelites. Chem Geol 279:55-62. https://doi.org/10.1016/j.chemg eo.2010.10.004

Spear FS, Pyle JM, Cherniak D (2009) Limitations of chemical dating of monazite. Chem Geol 266:227-239. https://doi.org/10.1016/j. chemgeo.2009.06.007

Stephens MB (1988) The Scandinavian Caledonides: a complexity of collisions. Geol Today 4:20-26 
Stephens MB, Van Roermund HLM (1984) Occurrence of glaucophane and crossite in eclogites of the Seve Nappes, southern Norrbotten Caledonides, Sweden. Nor Geol Tidsskr 64:155-163

Suzuki K, Adachi M (1991) Precambrian provenance and Silurian metamorphism of the Tsubonosawa paragneiss in the south Kitakami terrane, Northeast Japan, revealed by the chemical Th-U-total $\mathrm{Pb}$ isochron ages of monazite, zircon and xenotime. Geochem $\mathrm{J}$ 25:357-376

Svenningsen OM (2001) Onset of seafloor spreading in the Iapetus ocean at $608 \mathrm{Ma}$ : precise age of the Sarek Dyke Swarm, northern Swedish Caledonides. Precambrian Res 110:241-254. https://doi. org/10.1016/S0301-9268(01)00189-9

Tomkins HS, Powell R, Ellis DJ (2007) The pressure dependence of the zirconium-in-rutile thermometer. J Metamorph Geol 25:703-713. https://doi.org/10.1111/j.1525-1314.2007.00724.x

Walczak K, Anczkiewicz R, Szczepański J et al (2017) Combined garnet and zircon geochronology of the ultra-high temperature metamorphism: constraints on the rise of the Orlica-Śnieżnik Dome, NE Bohemian Massif, SW Poland. Lithos 293:388-400

Whitehouse MJ, Platt JP (2003) Dating high-grade metamorphismconstraints from rare-earth elements in zircon and garnet. Contrib Mineral Pet 145:61-74. https://doi.org/10.1007/s0041 $0-002-0432-z$

Williams ML, Jercinovic MJ, Hetherington CJ (2007) Microprobe monazite geochronology: understanding geologic processes by integrating composition and chronology. Annu Rev Earth Planet Sci 35:137-175. https://doi.org/10.1146/annurev.earth.35.03130 6.140228

Williams ML, Jercinovic MJ, Harlov DE et al (2011) Resetting monazite ages during fluid-related alteration. Chem Geol 283:218-225. https://doi.org/10.1016/j.chemgeo.2011.01.019

Williams ML, Jercinovic MJ, Mahan KH, Dumond G (2017) Electron microprobe petrochronology. Rev Mineral Geochem 83:153-177

Wing BA, Ferry JM, Harrison MT (2003) Prograde destruction and formation of monazite and allanite during contact and regional metamorphism of pelites: petrology and geochronology. Contrib Mineral Pet 145:228-250. https://doi.org/10.1007/s00410-003-0446-1

Woodhead J, Hergt J, Shelley M et al (2004) Zircon Hf-isotope analysis with an excimer laser, depth profiling, ablation of complex geometries, and concomitant age estimation. Chem Geol 209:121-135. https://doi.org/10.1016/j.chemgeo.2004.04.026

Zack T, Moraes R, Kronz A (2004) Temperature dependence of Zr in rutile: empirical calibration of a rutile thermometer. Contrib Mineral Pet 148:471-488. https://doi.org/10.1007/s00410-004-0617-8

Publisher's Note Springer Nature remains neutral with regard to jurisdictional claims in published maps and institutional affiliations. 